\title{
16. Türkçe ders kitaplarındaki metni anlama sorularının eleştirel düşünme becerilerine göre incelenmesi
}

\section{Funda AMANVERMEZ İNCİRKUŞı}

\section{Kübra ÖZÇETİN²}

\begin{abstract}
APA: Amanvermez İncirkuş, F.; Özçetin, K. (2021). Türkçe ders kitaplarındaki metni anlama sorularının eleştirel düşünme becerilerine göre incelenmesi. RumeliDE Dil ve Edebiyat Araşttrmaları Dergisi, (22), 290-311. DOI: 10.29000/rumelide.895805.
\end{abstract}

\section{$\ddot{\mathbf{O} z}$}

$\mathrm{Bu}$ çalışmada Türkçe 5-8. sınıf ders kitaplarında yer alan metni anlama ve değerlendirme sorularının eleştirel düşünme becerilerine göre dağılımı sınıf seviyesi (5-8) ve metin türüne göre incelenmiştir. Araştırma nitel araştırma yöntemlerinden doküman incelemesiyle yapılmıştır. Araştırmanın örneklemini 2020-2021 eğitim-öğretim yılında okutulacak Türkçe ders kitapları oluşturmaktadır. Örneklem seçimi amaçlı örnekleme yollarından ölçüt örnekleme yoluyla belirlenmiştir. Veriler doküman incelemesi yoluyla belirlenen ders kitaplarından toplanmıştır. Çalışmada Türkçe ders kitaplarında yer alan metni anlama soruları Amanvermez İncirkuş ve Beyreli (2019) tarafından geliştirilen “Türkçe derslerinde eleştirel düşünmeye yönelik beceriler ve soru örnekleri/kökleri” formuna göre incelenmiştir. Verilerin analizinde betimsel analiz ve içerik analizinden yararlanılmıştır. Güvenirlik için bağımsız değerlendirmeciler arası uyum çalışması yapılmıştır (Güvenirlik=\%83). Araştırmada elde edilen başlıca bulgular şöyledir: Bütün sınıf seviyelerinde ve metin türlerinde, tanımlama düzeyinde ve yorumlama düzeyinde yer alan ilişki kurmaya yönelik sorulara çok fazla yer verildiği görülmektedir. Yorumlama düzeyinde örtük anlam ve ana fikir bulma sorularına ise çok az yer verilmiştir. Öğrencinin kendi deneyim ve düşünceleriyle cevap vermesini gerektiren üst düzey düşünme becerilerini harekete geçirecek analiz, çıarım, varsayımda bulunma, açılama, değerlendirme becerilerine yönelik sorulara ya çok az yer verilmiştir ya da hiç yer verilmemiştir. Üst düzey düşünme gerektiren sorular kendi içerisinde değerlendirildiğinde açıklama ve değerlendirme sorularına yer verildiği görülmüştür. Ancak bu soruların oranı, tanımlama ve yorumlama sorularına oranla oldukça düşüktür. Bununla birlikte bu sorular, soru tipi olarak açıklama ve değerlendirme düzeyinde değerlendirilse de eleştirel düşünme açısından soruların basit düzeyde olduğu söylenebilir. Sonuç olarak sınıflara ve metin türlerine göre karşılaştırma yapıldığında eleştirel düşünme becerilerine yönelik soruların dağılımında 5. sınıftan 8. sınıfa doğru gidildikçe artan aşamalı bir dağılım görülmemektedir. Dolayısıyla metni anlama soruları hazırlanırken sorular aracılı̆̆ıyla eleştirel düşünme becerilerinin öğretilmesinde/geliştirilmesinde planlı bir eğitim yapılmadığı söylenebilir.

Anahtar kelimeler: Eleştirel düşünme, ders kitapları, metni anlama soruları

Dr. Öğr. Gör., Jandarma ve Sahil Güvenlik Akademisi, Sosyal Bilimler Bölümü (Ankara, Türkiye), fundaamanvermez@hotmail.com, ORCID ID: oooo-0oo2-5913-122X [Araştırma makalesi, Makale kayıt tarihi: 08.02.2021-kabul tarihi: 07.02.2021; DOI: 10.29000/rumelide.895805]

Dr. Arş. Gör., Marmara Üniversitesi, Atatürk Eğitim Fakültesi, Türkçe ve Sosyal Bilimler Eğitimi Bölümü, Türkçe Eğitimi ABD (İstanbul, Türkiye), kubra.ozcetin@marmara.edu.tr, ORCID ID: oooo-0002-5485-1586

Adres | Address

RumeliDE Dil ve Edebiyat Araşttrmaları Dergisi $\quad$ RumeliDE Journal of Language and Literature Studies Osmanağa Mahallesi, Mürver Çiçeği Sokak, No:14/8 Osmanağa Mahallesi, Mürver Çiçeği Sokak, No:14/8

Kadıköy - İSTANBUL / TÜRKIYE 34714 Kadıköy - ISTANBUL / TURKEY 34714 e-posta: editor@rumelide.com

e-mail: editor@rumelide.com

tel: +90 505 7958124, +90 2167730616 phone: +90 505 7958124, +90 2167730616 


\title{
Examining text comprehension questions in Turkish textbooks according to critical thinking skills
}

\begin{abstract}
In this study, the distribution of the comprehension and evaluation questions in the Turkish classroom textbooks (5-8.) according to critical thinking skills was examined according to grade level and text genre. The research was conducted by document analysis, one of the qualitative research methods. The universe of the research consists of 2020-2021 academic year Turkish textbooks. The selected books were determined by criterion sampling method from purposive sampling methods. The data were collected from the textbooks determined through document analysis. In the study, the text comprehension questions in Turkish textbooks were examined according to the "critical thinking skills and question samples/question statements in Turkish lessons " form developed by Amanvermez İncirkuş and Beyreli (2019). Descriptive analysis and content analysis were used to analyze the data. The reliability of the study was provided by the reliability of agreement between independent evaluators (Reliability $=83 \%$ ). The main findings of the study are as follows: In all grade levels and text types, it was observed that at the defination level and interpretation level, there was a lot of "cause and effect questions" questions but "finding implicit meaning" and "finding main idea" questions are given rarely. The questions about analysis, inference, assumptions, explanation, and evaluation skills that will activate the higher-order thinking skills that require the student to answer with his own experiences and thoughts are rarely or not included in the textbooks. When the questions requiring high-level thinking were evaluated within themselves, it was seen that explanation and evaluation questions were included, but the rate of these questions is very low compared to the definition and interpretation questions. However, although these questions are explanation and evaluation questions as question types, it can be said that the questions are simple questions in terms of critical thinking. As a result, when comparing according to classes and text types, there is no gradual distribution in the distribution of questions on critical thinking skills from $5^{\text {th }}$ grade to 8 th grade. While preparing the text comprehension questions, it can be said that there is no planned system in teaching/developing critical thinking skills through the questions.
\end{abstract}

Keywords: Critical thinking, textbooks, text comprehension questions

\section{Giriş}

Son yıllarda yaşanan teknoloji tabanlı gelişmeler, içinde yaşadığımız dünyayı küresel ve dijital olarak birbirine yakınlaştırmakta dolayısıyla bu yeni dünya anlayışının birey, toplum, iş, eğitim gibi yaşamın içindeki dinamiklerden beklentileri de farklılaşmaktadır. Ülkelerin ekonomik ve toplumsal kalkınmasında bireyin etkisi düşünüldügünde eğitim programlarının bu gelişmelerin beklentilerini karşılayacak şekilde yeniden yapılanması kaçınılmaz olmuştur. Bu doğrultuda 21. yüzyıl becerilerinin kazandırılması için Amerika Birleşik Devletleri’nde "21. Yüzyıl Öğrenme Ortaklı̆̆ (Partnership for 21st-Century)" isimli bir proje başlatılmıştır. Bu proje ülke çapında 21 eyalette uygulanmakta ve projeye iş dünyasından 33 farklı kurum destek vermektedir. Birçok ülke tarafından örnek alınan projenin temel amacı; değişimin ve öğrenmenin sürekli devam ettiği bir dünyada öğrencilerin başarılı olabilmesi için 21. yüzyll becerileriyle eğitim sistemlerini birleştirerek öğrencilerin öğrenme sürecine daha fazla dâhil olmalarını ve 21. yüzyılın beklentilerine hazır olmalarını sağlamaktır. Bu doğrultuda proje kapsamında eğitimciler, eğitim uzmanları ve iş dünyasından liderlerin katkılarıyla öğrencilerin 
Examining text comprehension questions in Turkish textbooks according to critical thinking skills / F. Amanvermez İncirkuş; K. Özçetin (pp. 290-311)

bireysel, toplumsal ve meslekî açıdan başarılı olabilmeleri için gerekli olan bilgi, beceri, uzmanlık ve destek sistemlerini tanımlayan ve gösteren çerçeve bir program hazırlanmıştır.

21. yüzyll çerçeve programına göre öğrenci kazanımları "temel/anahtar konular ve 21. yüzyıl temaları; öğrenme ve yenilik becerileri; bilgi, medya ve teknoloji becerileri; kariyer ve yaşam becerileri; 21. yüzyl destek sitemleri” olmak üzere dört boyutta ele alınmıştır (Framework for 21st-Century Learning, 2019). Öğrenci başarısı için çerçeve programda yer alan temel konularda -"ana dil (çerçeve program için İngilizce), okuma veya temel dil becerileri, dünya dilleri, sanat, ekonomi, fen bilimleri, coğrafya, tarih, yönetim ve vatandaşlık" - gerekli bilgi ve becerilere sahip olmak çok önemlidir. Bunun yanında öğrencilerin giderek karmaşıklaşan hayat şartlarına ve çalışma ortamlarına hazırlanmaları da gerekmektedir. Bu doğrultuda öğrencilere kazandırılması beklenen yaşam boyu öğrenme ve yenilik becerileri "iletişim, işbirliği, yaratıcllk ve yenilik, problem çözme ve eleştirel düşünme"dir (P21, 2019). Teknoloji ve medya odaklı bir dünyada öğrencilerin sadece öğrenme ortamlarında değil, bütün yaşam ve kariyer süreçlerinde içerik bilgisi, düşünme becerileri, sosyal ve duygusal yeterlilikleri gelişmiş etkili vatandaş ve/veya çalışan olabilmeleri için de eleştirel düşünme becerilerini sergileyebilmeleri gerekmektedir.

Dünyada değişen eğitim anlayışına ayak uydurmak için Türkiye'de de 2005 yllından itibaren öğretim programlarında çağın gereklerini karşlayacak düzenlemeler yapılmaktadır. Bu doğrultuda Türkçe öğretim programlarıla "bilgiyi üreten, hayatta işlevsel olarak kullanabilen, girişimci, kararl, iletişim becerilerine sahip, empati yapabilen, topluma ve kültüre katkı sağlayan, problem çözebilen ve eleştirel düşünebilen" bireyler yetiştirmek amaçlanmıştır (MEB, 2006; 2019). Revize edilen Türkçe Öğretim Programı (2019) incelendiğinde eleştirel düşünmenin öğretim programının hem genel hem de özel amaçları içerisinde yer aldığı, temel dil becerilerinin öğretilmesinde ve ölçme değerlendirmede de eleştirel düşünmeye vurgu yapıldığı görülmektedir. Eğitim Araştırma Geliştirme Daire Başkanlığı (EARGED, 2011, s. 291) tarafından 21. yüzyıl öğrenci profilini belirlemek için yapılan araştırmada da "eleştirel düşünme, problem çözme ve karar verme becerilerine sahip" bireyler yetiştirmek amaçlanmıştır. Başka bir deyişle MEB'in Türkçe öğretimi için belirlediği hedeflerde düşünme becerilerinin geliştirilmesine önem verildiği, bu beceriler içerisinde de eleştirel düşünmenin 21. yüzyll eğitim anlayışında önemli bir yer tuttuğu söylenebilir.

Literatürde eleştirel düşünmeyle ilgili farklı tanımlara rastlamak mümkündür. Bunun sebebi eleştirel düşünmenin tek bir beceriden veya sıralı beceri setlerinden oluşmamasından kaynaklanmaktadır. Farklı tanımlarda yer alan merak, analiz, çıkarım, problem çözme, yorumlama, değerlendirme vb. beceriler eleştirel düşünmenin gerçekleştiğini gösteren eğilim, davranış ya da durumdur (Nosich, 2015). Eleştirel düşünme, bu gibi becerileri içeren ve bunların bileşiminden oluşan üst düzey bir düşünme becerisidir. Bu bakımdan eleştirel düşünme temelde kişinin karar ve eylemlerini düzenlemesini ya da değiştirmesini sağlayan mantıklı düşünme, sebep-sonuç ilişkisi kurma, bakış açısı geliştirme, olasılıkları göz önünde bulundurma, problem çözme, ipuçlarından faydalanma gibi süreçleri içeren bir hayat becerisidir (Paul ve Elder, 2006; Willingham, 2007).

Willingham (2019), teknoloji ve yapay zekâ ekseninde gelişen dünyada toplumsal ve ekonomik başarının gerçekleşmesi için eleştirel düşünme becerisinin temel bir yapı taşı olduğunu, bundan dolayı eğitim ortamlarının eleştirel düşünme becerilerini geliştirecek şekilde düzenlenmesi gerektiğini belirtmiştir. Okullarda eleştirel düşünmenin öğretilmesi için dört aşamalı bir süreç göz önünde bulundurulmalıdır (Willingham, 2019):

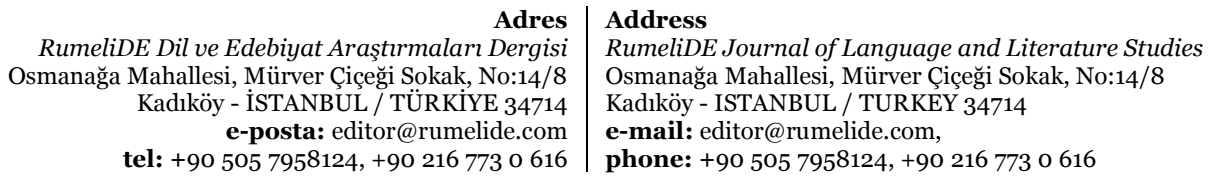

RumeliDE Dil ve Edebiyat Araşttrmaları Dergisi ( e-posta: editor@rumelide.com tel: +90 $5057958124,+902167730616$
Address

OsmeliDE Journal of Language and Literature Studies

e-mail: editor@rumelide.com

phone: +90 5057958124, +90 2167730616 
1. Her disiplin kendi konu alanı için gerekli olan eleştirel düşünme becerilerini belirlemeli,

2. Belirlenen eleştirel düşünme becerileriyle bütünleşecek konu içerikleri belirlenmeli,

3. Öğretilecek bilgi ve beceriler dersin (konunun) akışına uygun olarak planlanmalı,

4. Yıllar içinde hangi bilgi ve becerilerin yeniden gözden geçirilmesi gerektiği planlanmalıdır.

Eleştirel düşünme öğretiminde yukarıdaki süreç işletilirken doğru soruları sormak önemlidir çünkü eleştirel düşünme soru sormayla başlar (King, 1995; Schmit, 2002; Facione, 2015; Nosich, 2015). Tam ve gerçekçi bir eleştirel düşünmenin gerçekleşebilmesi için konunun özüne giden iyi soruların mantıklı gerekçelerle çözümlenmesi ve ortaya çıkan sonuçlara dayalı olarak davranış, durum vb. değişikliği olması gerekir. Eleştirel düşünme öğretiminde bir problemin farkına vararak o problemin (konunun) hangi yönlerden nasıl ele alınacağına yönelik amaçlar, çözümler, alternatifler belirlemek ve bunu sonraki öğrenmelere transfer etmek önemlidir. Bu bakımdan eleştirel düşünme becerisini geliştirmeye yönelik soru hazırlanırken bu hususların göz önünde bulundurulması gerekir.

Ancak öğrencilerin çoğunun soru sormayl, kendileri veya çeşitli durumlar hakkında olumsuz değerlendirmeler veya faydasız genellemeler yapmak için kullandıkları bilinmektedir (Nosich, 2015). Bu genellikle doğru soru sorulsa bile yanlış çözümleme tekniklerinden (başkasının cevabını basitçe kabul etme, akla ilk geldiği gibi cevap verme, yetiştirilme tarzı ve kişilik özelliklerini dikkate almadan cevap verme vb.) kaynaklanır (Nosich, 2015). Bu bakımdan eleştirel düşünme eğitiminde öğretmenin de eleştirel düşünebilmesi ve açı öğretim yoluyla kendi düşünme, sorgulama sürecini öğrencilere göstererek onlara iyi bir model olması gerekir (Paul, 2012, s. 519, 521). Bunun yanında öğretmen öğrencilerin bağımsız eleştirel düşünen bireyler olabilmeleri için ele alınan konuyla ilgili içerik bilgisi oluşturmalı; uygun strateji ve yöntemlerle öğrencilere uygulama yaptırmalıdır (Willingham, 2007; Schmit, 2002).

Öğrencilerin sınıf ortamında eleştirel düşünme becerilerinin gelişebilmesi için açı uçlu sorularla ve gerçek hayat problemleriyle karşılaşmaları gerekmektedir (Lynch ve Wolcott, 2001; Willingham, 2019). Bu tip sorular öğrencilerin analiz, çıkarım, değerlendirme gibi üst düzey düşünme becerilerini harekete geçirir (MacKnight, 2000). Gelişimin aşamalı olduğu dikkate alındığında her sınıf düzeyinde sorulan soruların düzeylerinin farklılaşması olağandır. Bununla birlikte sorulan sorularda içeriği göz önünde bulundurarak düzeye uygun soru sormaya dikkat etmek gerekir.

Raphael ve Au (2005, s. 212, 215) sınıf içi uygulamalarda öğrencilerin farklı soru tiplerini öğrenerek düşünme ve yorumlama becerilerini geliştirebilmesi için dört farklı soru biçiminden bahsetmiştir. Bunlardan ilki metinde cevapları bir kelime, kelime grubu veya cümle şeklinde aynen bulunan sorulardır. İkinci tip sorular, cevabı metinde bulunan ancak öğrencinin farklı paragraflardaki cümleleri/bilgileri birleştirerek başka bir deyişle cevabı kendi cümleleriyle dönüştürerek metnin farklı kısımlarını bir araya getirmesiyle cevaplayabileceği sorulardır. Üçüncü tip sorular cevabı metinde olmayan ancak metinle ilişkili sorulardır. Öğrencinin bu tip sorulara cevap verebilmesi için metni okuması, anlaması ve/veya önceki bilgileriyle ilişki kurması gerekir (Ana fikir/yardımcı fikir soruları bu tip sorulara örnek olabilir.). Dördüncü tip sorularsa cevabı metinde olmayan sorulardır. Öğrenci kendi deneyimlerini/bilgilerini kullanarak bu tip sorulara cevap arar.

Sinıf ortamında eleştirel düşünme sürecini işleten sorular aracıllğıyla öğrencilerin eleştirel düşünme becerilerini geliştirmek amaçlanıyorsa öncelikle hangi disiplin alanında hangi düzeyde hangi beceri ve kriterler üzerinde durulacağı belirlenmelidir. Örneğin eleştirel düşünme becerilerinden olasılıkları göz önünde bulundurma/varsayımda bulunma becerisi/kriteri ele alındığında matematik dersinde 6 . sinıf

Adres Address

RumeliDE Dil ve Edebiyat Araştırmaları Dergisi $\quad$ RumeliDE Journal of Language and Literature Studies Osmanağa Mahallesi, Mürver Çiçeği Sokak, No:14/8 Osmanağa Mahallesi, Mürver Çiçeği Sokak, No:14/8 Kadıköy - ISTANBUL / TÜRKIYE 34714 Kadıköy - ISTANBUL / TURKEY 34714 e-posta: editor@rumelide.com e-mail: editor@rumelide.com, tel: +90 505 7958124, +90 2167730616 phone: +90 505 7958124, +90 2167730616 
Examining text comprehension questions in Turkish textbooks according to critical thinking skills / F. Amanvermez İncirkuş; K. Özçetin (pp. 290-311)

düzeyinde öğretmenin öğrenciden beklentisi farklıyken; Türkçe dersinde olasılıkları göz önünde bulundurma kriteri için öğrenciden beklenilen farklıdır. Dolayısıyla öncelikle belirlenen disiplin alanına özgü kriter tanımlarının yapılması gerekir. Daha sonra belirlenen beceri/kriterlerle dersin içeriğini bütünleştirecek konu içerikleri belirlenmelidir. Dersin işlenişi, uygun yöntem ve tekniklerle planlanırken sorulacak sorular da dersin amacına/hedefine uygun biçimde belirlenen kriterlere yönelik olarak hazırlanmalı ve süreç değerlendirilerek öğrenciye dönüt verilmelidir.

Temel eleştirel düşünme becerilerinin neler olduğu ve bunların hangi soru tipleriyle karşllanabileceğine yönelik yapılan "Delfi Projesi"nde "yorumlama, analiz, çıkarım, değerlendirme, açılama, öz-düzenleme” becerilene yönelik sorulara yer verilmiştir (Facione, 2015). Farklı çalışmalarda da bu becerilere ek olarak "tanımlama, analiz, bakış açısı geliştirme, varsayımda bulunma, uygulama, karşlaştırma, gerçek hayata uyarlama” gibi beceri alanlarında eleştirel düşünme sorularının sorulabileceği belirtilmiştir (King, 1995; Browne ve Keeley, 2007; Learning Development, 2010; Facione, 2015). Burada kavramlar değişse de bazı çalışmalarda daha genel kavramların içeriğinde ayrıntıya gidildiği bazılarında ise detaylı kavramlaştırma yapıldı̆̆ı görülmektedir. Ancak eleştirel düşünmeyi temelde belirleme, analiz ve değerlendirme olmak üzere üç boyutta ele alan çalışmaların içeriğine bakıldığında diğer kavramların bu kavramların içerik tanımlarıyla bütünleştirildiği görülmektedir. Alan yazındaki birçok çalışmanın incelenmesi sonucunda Amanvermez-İncirkuş ve Beyreli (2019) tarafından Türkçe derslerinde eleştirel düşünme becerilerini geliştirmek ve değerlendirmek için beceriler, beceri tanımları, alt beceriler ve örnek soru tipleri/kökleri belirlenmiştir (Ek-1). Eleştirel düşünebilmek için içerik bilgisi de önemli olduğundan (Willingham, 2007) yapılan çalışma sonucunda metnin içeriğini anlamak için tanımlama, yorumlama; metni derinlemesine anlamak için de analiz, çıkarım, açıklama, varsayımda bulunma ve değerlendirme becerileri eleştirel düşünme becerileri olarak belirlenmiştir.

Türkçe derslerinin daha çok okuduğunu/dinlediğini anlama ve değerlendirmeye dayalı olarak gerçekleştiği düşünüldüğünde tematik olarak hazırlanan ders kitapları aracılığıyla eleştirel düşünme becerilerinin geliştirilebilmesi için öğrenci düzeyine uygun, gerçek hayatla ilişkilendirilebilecek açık uçlu soruların dikkatle hazırlanması gerektiği söylenebilir. Sorular hazırlanırken yukarıda belirtildiği üzere (MacKnight, 2000; Nosich, 2015; Willingham, 2019) hangi sınıf düzeyinde hangi beceriler öğretilmek isteniyorsa bunlara uygun kriterlerin ve kriterleri tanımlayan soru tiplerinin içeriğe uygun biçimde belirlenmesi gerekir. Çünkü soru sorma, öğretmenlerin öğrencilerin öğrenme sürecine destek olmalarını ve eleştirel düşünme becerilerini geliştirmelerini teşvik etmelerini sağlayan bir öğretim ve değerlendirme aracıdır (Ritchhart, Church ve Morrison, 2011). Soru sormak kadar soruları cevaplamak da önemlidir. Öğrencileri eleştirel düşünmeye ve üst düzeylerde cevap vermeye teşvik edebilmek için öğretmenin sorduğu, öğrencinin cevapladığı ve öğretmenin doğru/yanlış diyerek basit düzeyde değerlendirmesiyle noktalanan geleneksel soru cevap etkinliklerinden (bilgiyi hatırlayarak cevap verilen ya da doğrudan bilgi isteyen sorular) kaçınmak gerekir. Bunun yerine verilen cevaplardan yola çıkarak öğrenciyi düşünmeye sevk edecek bir soru-cevap döngüsü oluşturabilecek açık uçlu sorulardan yararlanmak gerekir (Ford-Connors ve Robertson, 2017).

Türkçe Öğretim Programı’nda (MEB, 2019a) da gerçek hayata dair sorular aracıllğıyla öğrencilerin çıkarım yaparak konuyla ilgili bilgi ve becerilerini gerçek hayat durumlarında nerede, nasıl kullanabileceklerine dair üst düzey farkındalık becerilerini geliştirebilecekleri belirtilmiştir. Bundan dolayı yaşam boyu öğrenen 21. yüzyll öğrenci profilini oluşturabilmek için eleştirel düşünme becerilerini geliştiren soruların Türkçe ders kitaplarında bilinçli bir şekilde yer alması gerektiği söylenebilir.

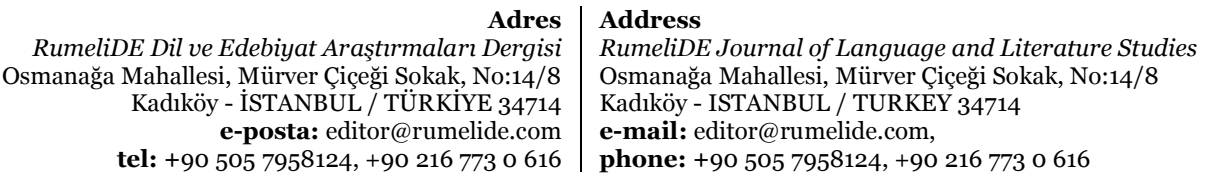


Yapılan çalışmalara bakıldığında Türkçe ders kitaplarında yer alan metni anlama ve değerlendirme sorularının PISA'daki bilişsel alanlara, çeşitli değişkenlere ve taksonomilere göre incelendiği görülmektedir (Özkaya, 2020; Diker Coşkun, 2013; Özdemir, 2011; Şahin, 2006) . Ancak metni anlama ve değerlendirme sorularının eleştirel düşünme becerilerini geliştirmeye uygun olup olmadığı değerlendirilmemiştir. Eğitimin amaçları arasında bireyleri hayata hazırlamak olduğu düşünüldüğünde temel bir yaşam becerisi olan eleştirel düşünmenin öğretilmesi 21. yüzyll için kaçınılmazdır. Öğretmenlerin ve öğrencilerin Türkçe derslerinde en çok başvurduğu materyal ders kitaplarıdır. Dolayısıyla Türkçe derslerinde öğrencilerin farklı bakış açıları kazanmaları, öğrenmeyi öğrenme ve üst düzey düşünme gibi becerilerinin dersin içeriğiyle bütünleştirilerek geliştirilmesi de ders kitapları aracılığıyla sağlanacaktır. Bu bakımdan eleştirel düşünme eğitiminde önemli adımlardan biri olan sorgulamanın hazırlanan ders kitaplarında yer alan sorular aracılığıyla gerçekleşeceği dolayısıyla bu soruların öğrencileri hayata hazırlayan ve üst düzey düşünmeye teşvik eden nitelikte olması gerektiği söylenebilir. Bu çalışmada amaç Türkçe 5-8. sınıf ders kitaplarında yer alan metni anlama ve değerlendirme sorularının eleştirel düşünme becerilerine göre incelenmesidir. $\mathrm{Bu}$ doğrultuda aşağıdaki sorulara cevap aranmıştır:

1. Türkçe ders kitaplarında yer alan metni anlama sorularının eleştirel düşünme becerilerine göre dağılımı sınıf seviyesine göre nasıldır?

2. Türkçe ders kitaplarında yer alan metni anlama sorularının eleştirel düşünme becerilerine göre dağılımı metin türlerine göre nasıldır?

3. Metin türlerine göre Türkçe ders kitaplarında yer alan metni anlama sorularının eleştirel düşünme becerilerine göre dağılımı farklı sınıf seviyelerinde nasıldır?

Soru analizi için kullanılan "Türkçe derslerinde eleştirel düşünmeye yönelik beceriler ve soru örnekleri/kökleri” formunun metni anlama sorularının eleştirel düşünmeye uygunluğunu değerlendirmek için yeterli olduğu varsayılmıştır. Çalışma, kullanılan ders kitapları ve veri toplama araciyla sinırlıdır.

\section{Yöntem}

\section{Araştırma deseni}

Türkçe ders kitaplarında yer alan metni anlama sorularının eleştirel düşünme düzeylerine göre incelendiği ve sınıflandırıldığı bu araştırma nitel araştırma yöntemlerinden doküman incelemesiyle yapılmıştır. Doküman, araştırma öncesinde mevcut olan herhangi bir şeydir. Doküman incelemesi yönteminde araştırılacak konuya uygun olan belgeler seçilerek sistematik bir biçimde analiz edilir (Merriam, 2018, s. 142).

\section{Örneklem seçimi}

Araştırmanın örneklemini 2020-2021 eğitim-öğretim yllında okutulacak Türkçe ders kitapları oluşturmaktadır. Talim ve Terbiye Kurulu Başkanlığının Tebliğler Dergisinde yer alan Aralık 20192747-EK kararıyla 2020-2021 eğitim-öğretim yılında Türkçe derslerinde okutulması uygun görülen kitaplar Tablo 1.'de gösterilmiştir:

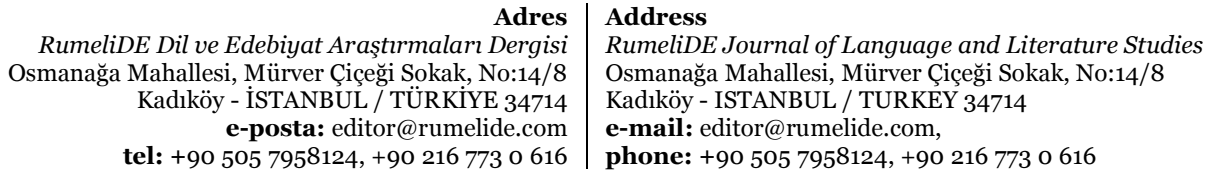

tel: +90 505 7958124, +90 2167730616 
Examining text comprehension questions in Turkish textbooks according to critical thinking skills / F. Amanvermez İncirkuş; K. Özçetin (pp. 290-311)

Tablo 1. Araştırmanın evrenini oluşturan Türkçe ders kitapları

\begin{tabular}{lll}
\hline Kitabın Adı & Yazarı/Yazarları & Yayınevi \\
\hline $\begin{array}{l}\text { Ortaokul ve İmam } \\
\text { Hatip Ortaokulu } \\
\text { Türkçe 5 }\end{array}$ & Şule ÇAPRAZ BARAN, Elif DİREN & Anıttepe Yay./Ank. \\
& Himmet AÇIKGÖZ, Deniz TURAN & Uygun Basın Yay./İst. \\
& Özlem ESEN & Tuna Mat./Ank. \\
& Seyhan Kübra ESMER, Beyhan KEÇELİ & Ilke Basım Yay./Ank \\
\hline Ortaokul ve İmam & Nihal ERTÜRK, Seray KELEŞ, Damla KÜLÜNK & Millî Eğt. Yay. \\
Hatip Ortaokulu & Gülten ERKEK, Kadir DURU, Murat & Millî Eğt. Yay. \\
Türkçe 6 & PASTUTMAZ, Sabri CEYLAN & Ata Yay./Ank. \\
& Mehmet Ozan SARIBOYACI & Dikey Yay./Ank. \\
& Deniz YAVUZ KILIÇ, Gökmen KAHRAMAN & Ekoyay Eğitim Yay./Ank. \\
& Tuncay DEMİREL & Gezegen Yay./Ank. \\
& Yasemin ŞEKERCİ & \\
\hline Ortaokul ve İmam & Ahmet AKGÜL, Ali UYSAL, Duygu KARADAŞ, & Millî Eğt. Yay. \\
Hatip Ortaokulu & Ebubekir GÜRCAN, İlkay KARAHAN, Nurcihan & Millî Eğt. Yay. \\
Türkçe 7 & DEMİRER & Özgün Mat./Ank. \\
& Emine KIRMAN, Seda YAĞIZ, Tolga KIR & Dörtel Yay./Ank. \\
& Hilal ERKAL, Mehmet ERKAL & Ders Destek Yay./Ank. \\
Hürkçe 8 & Nihat ERDAL & \\
\hline Ortaokul ve İmam & Burçak KAYA & \\
\hline
\end{tabular}

Çalışmada 5. sınıflarda Anıttepe Yayıncılık'ın hazırladığı kitap kullanılmıştır. 6, 7 ve 8. sınıflarda ise MEB’in hazırladığı kitaplar kullanılmıştır. Bu doğrultuda 5. sınıflarda yukarıdaki tabloda yayınevi başlı̆̆ı altında 1. sırada bulunan Anıttepe; 6. sınıflarda 2. sırada bulunan Millî Eğitim; 7. sınıflarda 2. sırada bulunan Millî Eğitim; 8. sınıflarda 1. sırada bulunan Millî Eğitim Yayınlarına ait ders kitapları örneklem olarak belirlenmiştir. Daha sonra araştırma amacına uygun olarak belirtilen ders kitaplarında bulunan metni anlama soruları amaçlı örnekleme yoluyla eleştirel düşünme becerilerine göre incelenmiştir. "Ölçüt örnekleme, örneklemin problemle ilgili olarak belirlenen niteliklere sahip kişiler, olaylar, nesneler ya da durumlardan oluşturulmasıdır.” (Büyüköztürk, Ş. vd. 2012)

\section{Verilerin toplanması}

Veriler doküman incelemesi yoluyla belirlenen ders kitaplarından toplanmıştır. Patton (2002, s. 293) eğitimle ilgili konularda öğretim programlarında belirtilen ve program için hazırlanan resmî olan ve olmayan dokümanların incelenebileceğini belirtmiştir. Eğitimle ilgili doküman türleri: görüşler, kanun maddeleri, çeşitli raporlar, kurumlara veya şahıslara ait kayıtlar, istatistikî veriler, toplum bilimi alan notları, günlükler, gazeteler, fotoğrafalar, kitaplar vb. olabilir (Merriam, 2018).

Çalışmada Türkçe ders kitaplarında yer alan metni anlama soruları Amanvermez İncirkuş ve Beyreli (2019) tarafından oluşturulan "Türkçe derslerinde eleştirel düşünmeye yönelik beceriler ve soru örnekleri/kökleri” formuna göre incelenmiştir. Bu form Türkçe derslerinde öğrencilerin eleştirel düşünme becerilerini değerlendirmeye yönelik analitik bir rubrik oluşturma sürecinde geliştirilmiştir. Bu sayede Türkçe derslerinde ölçülebilecek eleştirel düşünme becerileri/alt becerileri ve bu becerileri karşlayan soru tipleri uzman görüşüne dayalı olarak belirlenmiştir.

\begin{tabular}{|c|c|}
\hline & \\
\hline alarn $D$ & d Literatur \\
\hline $\mathrm{Mal}$ & Mahallesi, Mürver Çiçeği Sokak, No:14/8 \\
\hline Kadıköy & STANBUL / TURKEY 34714 \\
\hline $\begin{array}{r}\text { e-posta: edito } \\
\text { tel: }+905057958124,+\end{array}$ & $\begin{array}{l}\text { editor@rumelide.com, } \\
\text { +90 505 7958124, +90 } 216773 \text { o } 616\end{array}$ \\
\hline
\end{tabular}


Literatür tarandığında eleştirel düşünmeyle ilgili farklı tanımlara ve becerilere rastlamak mümkündür çünkü eleştirel düşünme bağlamdan bağımsız olarak gerçekleşmez. Eleştirel düşünmenin tanımında yer alan üst düzey düşünme becerileri eleştirel düşünmenin varlığını gösteren davranış, tutum veya eğilimlerdir (Nosich, 2015). Bundan dolayı her disiplin alanı üst düzey düşünme becerilerini geliştirmeye yönelik olarak kendine özgü kriter tanımları oluşturmalıdır.

Hazırlanan formda (Amanvermez-İncirkuş ve Beyreli, 2019) eleştirel düşünme konusunda yapılan birçok araştırma ve ölçek incelenmiştir (King, 1995; Ennis ve Millman, 2005; Learning Development, 2010; Facione, 2015). Formu hazırlayan araştırmacılar tarafından literatür taraması sonucunda ölçülebilecek 14 madde belirlenmiş ve bu maddeler 9 uzman görüşüne ( 9 uzman için kapsam geçerlik oranı=0.75'tir) sunulmuştur. Uzman görüşleri Lawshe tekniğine göre analiz edilmiştir. Analiz sonucunda Türkçe derslerinde sorular aracıllğıyla ölçülebilecek eleştirel düşünme becerileri içeriği anlama ve derinlemesine anlama boyutları altında toplanmıştır. İçeriği anlama boyutunda KGi (kapsam geçerlik indeksi) $=0.89$; derinlemesine anlama boyutunda $\mathrm{KG} \dot{\mathrm{I}}=0,87$ olarak bulunmuştur. İçeriği anlama boyutunda tanımlama ve yorumlama; derinlemesine anlama boyutunda analiz, çıkarım, açlklama, varsayımda bulunma ve değerlendirme kriterleri eleştirel düşünme becerileri olarak belirlenmiştir (EK-1). Yapılan işlemler formun geçerli bir form olduğunu göstermektedir.

Belirlenen dört ders kitabının her birinde sekiz tema bulunmakta ve her temada dört metin bulunmaktadır. İncelenen 128 metin içerisinde birkaç metinde metni anlama sorularının farklı etkinliklere dağıtıldığı (örneğin: 5. sınıf Türkçe ders kitabı, İyiliğin Değerini Bilen Kim? metninin etkinlikleri); birkaç metinde metni anlama sorularının öğrenciler tarafından oluşturulması istendiği; çoğu metinde ise soruların belirgin bir şekilde tek bir etkinlikte toplandığı görülmüsştür. Etkinlikler incelenerek ders kitaplarında yer alan metni anlama soruları belirlenmiştir. Sınıf seviyesine göre metin türlerinin sayısı tablo 2'de gösterilmiştir.

Tablo 2. Sınıf seviyesine göre metin türlerinin sayısı

\begin{tabular}{lllll}
\hline Metin türü & $5 \cdot$ sinif & 6 . sinıf & 7 . sinif & 8. sinif \\
\hline Öyküleyici & 15 & 14 & 17 & 14 \\
Bilgilendirici & 11 & 14 & 12 & 12 \\
Şiir & 6 & 4 & 3 & 6 \\
Toplam & 32 & 32 & 32 & 32 \\
\hline
\end{tabular}

\section{Verilerin analizi}

Verilerin analizinde betimsel analiz ve içerik analizinden yararlanılmıştır. Metni anlama soruları betimsel analizle Amanvermez-İncirkuş ve Beyreli (2019) tarafından geliştirilen eleştirel düşünme becerilerine uygun olarak kod ve kategorilere ayrılmıştır. İçerik analiziyle ders kitaplarında yer alan metni anlama soruları önceden belirlenmiş kod ve kategorilere göre incelenmiştir.

Metni anlamaya yönelik sorular tespit edildikten sonra alan uzmanı iki değerlendirmeci tarafından ders kitaplarında yer alan 761 soru eleştirel düşünme düzeylerine göre tek tek incelenerek sınıflandırılmıştır. Sınıflandırma yapılırken değerlendirmeciler öncelikle birbirlerinden bağımsız olarak soruları değerlendirmiştir. Daha sonra iki değerlendirmeci bir araya gelerek yaptıkları sınıflandırmayı eş zamanlı karşılaştırarak çalışmanın güvenirliğini sağlamışlardır. Güvenirlik için Miles ve Huberman'ın (1994) güvenirlik formülü kullanılmıştır [Güvenirlik=Görüş birliği/(görüş

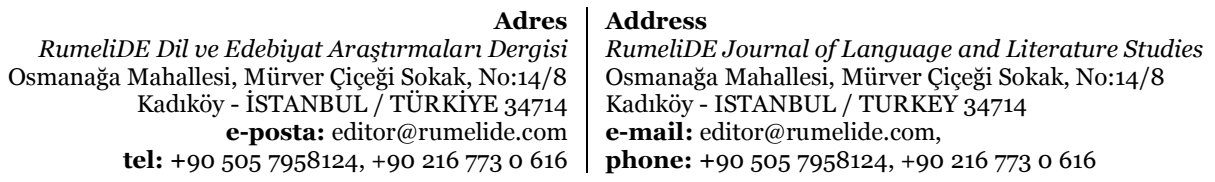


Examining text comprehension questions in Turkish textbooks according to critical thinking skills / F. Amanvermez İncirkuş; K. Özçetin (pp. 290-311)

birliği + görüş ayrıllı̆ı)**100]. Bu formüle göre \%80 ve üzerinde çıkan sonuçlar güvenirlik için yeterlidir. Hesaplamanın sonunda güvenirlik \%83 çıkmıştır. Son olarak görüş ayrılığı bulunan sorular tekrar incelenerek araştırmacıların ortak kararıyla uygun kategorilere yerleştirilerek güvenirlik işlemi tamamlanmıştır.

Sinıflandırmanın tutarlılığı tespit edildikten sonra her ders kitabı için her bir eleştirel düşünme düzeyinin metni anlama soruları içerisindeki toplamı $(f)$ ve yüzdeleri (\%) sınıf düzeylerine ve metin türlerine (öyküleyici, bilgilendirici, şiir) göre hesaplanmıştır. Metni anlama sorularının sınıf düzeylerine ve metin türlerine göre dağılımı ayrı ayrı incelenerek sınıf düzeyine ve metin türüne göre farklılık gösterip göstermediği incelenmiştir. Metinlerin bilgilendirici veya öyküleyici olarak sınıflandırılmasında metnin alt türü değil (anı, tiyatro, deneme vb.) metinde kullanılan anlatım yöntemi tercih edilmiştir. Örnek veri analizi Tablo 3’te gösterilmiştir.

Tablo 3. Eleştirel düşünme düzeylerine göre örnek veri analizi

\begin{tabular}{|c|c|c|}
\hline $\begin{array}{l}\text { Eleştirel } \\
\text { Düşünme } \\
\text { Düzeyleri }\end{array}$ & Örnek Soru & $\begin{array}{l}\text { Kitapta Bulunduğu } \\
\text { Yer }\end{array}$ \\
\hline Tanımlama & $\begin{array}{l}\text { 1. "Ulaşım nedir?" } \\
\text { 2. "Tarih öncesinde yaşayan insanlar zamanı kaç bölüme } \\
\text { ayırırdı?" } \\
\text { 3. "Hasan ve ağabeyi neler yapmaktan hoşlanmaktadır?" }\end{array}$ & $\begin{array}{l}\text { 1. 5. sinıf, Akıllı Ulaşım } \\
\text { Sistemleri, 1. Soru (s. 233) } \\
\text { 2. 6. sınıf, İnsanlar } \\
\text { zamanı eskiden nasıl } \\
\text { ölçerdi?, 1. Soru (s. 86) } \\
\text { 3. 8. sınıf, Kaşağı, 1. Soru } \\
\text { (s. 23) }\end{array}$ \\
\hline
\end{tabular}

\begin{tabular}{|c|c|c|c|}
\hline \multicolumn{4}{|l|}{ Yorumlama } \\
\hline \multirow{3}{*}{$\begin{array}{l}\text { (İlişki } \\
\text { Kurma) }\end{array}$} & \multicolumn{2}{|c|}{ 1. "Yazar, ă̆abeyine neden gücenmiştir? Açıklayınız." } & 1. 6. sinif Canım \\
\hline & \multirow{2}{*}{\multicolumn{2}{|c|}{$\begin{array}{l}\text { 2. "Güniz Hanım’n okul müdür yardımcısının yanına gitme nedeni } \\
\text { nedir?” }\end{array}$}} & Kitaplığım, 3. Soru (s. 28) \\
\hline & & & $\begin{array}{l}\text { 2. 6. sinif, Sen de Bir Iyilik } \\
\text { Yap, 3. Soru (s. 253) }\end{array}$ \\
\hline \multirow{3}{*}{$\begin{array}{l}\text { Yorumlama } \\
\text { (örtük } \\
\text { anlam) }\end{array}$} & \multirow{2}{*}{\multicolumn{2}{|c|}{$\begin{array}{l}\text { 1. "Şïrde geçen "İnliyordu dağın ardı, yasla" sözüyle anlatılmak } \\
\text { istenen nedir? Dağın ardında ne yaşanmaktadır?” }\end{array}$}} & 1. 5. sinif, Mustafa \\
\hline & & & (s. 42) \\
\hline & \multicolumn{2}{|c|}{$\begin{array}{l}\text { 2. "Yaş kesen, baş keser!, diyen dede etrafindaki insanlara hangi } \\
\text { mesajı vermeye çalışıyor? Açılayınız." }\end{array}$} & $\begin{array}{l}\text { 2. 7. sinif, Ağaçtan Oyma } \\
\text { Su Tası 3. Soru (s. 251) }\end{array}$ \\
\hline \multirow{3}{*}{$\begin{array}{l}\text { Yorumlama } \\
\text { (Ana Fikir } \\
\text { vb.) }\end{array}$} & \multirow{3}{*}{\multicolumn{2}{|c|}{$\begin{array}{l}\text { 1. "Metnin ana fikri nedir?" } \\
\text { 2. "Metnin konusu ve ana fikri nedir?” }\end{array}$}} & 7. sınıf, Mürefteli Kadınlar \\
\hline & & & \\
\hline & & & $\begin{array}{l}\text { 6. Sinıf, Canım Kitaplığım, } \\
\text { 4. Soru (s. 28) }\end{array}$ \\
\hline \multirow[t]{2}{*}{ Analiz } & \multicolumn{2}{|c|}{$\begin{array}{l}\text { 1. "Suların Kirlenme Nedenleri Nelerdir?, başliğı altında verilen } \\
\text { maddelerden hareketle asıl kirleticilerin kim olduğunu bulabildiniz } \\
\text { mi? Nedenleriyle açıklayını." }\end{array}$} & $\begin{array}{l}\text { 1. 6. sinif, Su Kirliliği } 3 . \\
\text { Soru (s. 154) }\end{array}$ \\
\hline & \multicolumn{2}{|c|}{$\begin{array}{l}\text { 2. “Sizce ebru sanatını sosyal ve kültürel yönlerden insanlara } \\
\text { katkıları neler olabilir?” }\end{array}$} & $\begin{array}{l}\text { 2. 7. sinıf Geleneksel Türk } \\
\text { Sanatlarından Ebru } 8 . \\
\text { Soru (s. 243) }\end{array}$ \\
\hline \multirow[t]{2}{*}{ Çıkarım } & \multirow{2}{*}{\multicolumn{2}{|c|}{$\begin{array}{l}\text { 1. “Okuduğunuz metinden çıkardığınız sonuç nedir?” } \\
\text { 2. “Metinden hareketle dönemsel ve toplumsal yapıyla ilgili hangi } \\
\text { çıkarımlarda bulunabilirsiniz? Metinden örnekler vererek }\end{array}$}} & 1. 8. sınıf Bayrağımızın \\
\hline & & & $\begin{array}{l}\text { Altında 6. Soru (s. 49) } \\
\text { 2. 5. sinıf, Dumlupınar }\end{array}$ \\
\hline & $\begin{array}{r}\text { Adres } \\
\text { RumeliDE Dil ve Edebiyat Arassttrmaları Dergisi } \\
\text { Osmanağa Mahallesi, Mürver Çiçeği Sokak, No:14/8 } \\
\text { Kadıköy - İSTANBUL / TÜRKiYE 34714 } \\
\text { e-posta: editor@rumelide.com } \\
\text { tel: +90 505 7958124, +90 } 216773 \text { o } 616\end{array}$ & \multicolumn{2}{|c|}{$\begin{array}{l}\text { Address } \\
\text { RumeliDE Journal of Language and Literature Studies } \\
\text { Osmanağa Mahallesi, Mürver Çiceği Sokak, No:14/8 } \\
\text { Kadıköy - ISTANBUL / TURKEY } 34714 \\
\text { e-mail: editor@ @rumelide.com, } \\
\text { phone: +90 505 7958124, +90 } 216773 \text { o } 616\end{array}$} \\
\hline
\end{tabular}




\begin{tabular}{|c|c|c|}
\hline & açıklayınız." & Savaşı, 5. Soru (s. 49) \\
\hline Açıklama & $\begin{array}{l}\text { 1. “Kültürler arası iletişimin sağlanmasında yabancı dil bilmenin } \\
\text { önemli olduğunu düşü- } \\
\text { nüyor musunuz? Açılayınız." } \\
\text { 2. "Sizce dilimizde kullanılan yabancı kelimelerin artış sebebi ne } \\
\text { olabilir? Açılayını." }\end{array}$ & $\begin{array}{l}\text { 2. 6. sinif, Ariyorum, } 5 \text {. } \\
\text { soru (s. 20) }\end{array}$ \\
\hline $\begin{array}{l}\text { Varsayımda } \\
\text { Bulunma }\end{array}$ & $\begin{array}{l}\text { 1. “Sığırtmaç Mustafa subay olduktan sonra Atatürk'le karşılaşmış } \\
\text { olsaydı neler hissederdi?” } \\
\text { 2. “Uygurlar niçin göç edip Beş Bahg'a yerleşmiştir? Uygurların } \\
\text { buradaki yaşamı sizce nasıl devam etmiş olabilir?” }\end{array}$ & $\begin{array}{l}\text { 1. 7. Sinıf, Sı̆̆ı̆rtmaç } \\
\text { Mustafa'nın Öyküsü, } 6 \text {. } \\
\text { Soru (s. 56) } \\
\text { 2. 8. sınıf, Göç destanı, } 7 \text {. } \\
\text { Soru (s. 181) }\end{array}$ \\
\hline \multirow[t]{2}{*}{$\begin{array}{l}\text { Değerlendir } \\
\text { me }\end{array}$} & $\begin{array}{l}\text { 1. "Aile bireylerinizi iyimserlik ve kötümserlik açısından } \\
\text { değerlendiriniz." }\end{array}$ & $\begin{array}{l}\text { 1. 8. sinif, İyimserlik ve } \\
\text { Kötümserlik Üzerine, } 6 \text {. } \\
\text { soru (s. 15) }\end{array}$ \\
\hline & $\begin{array}{l}\text { 2. “Atıl'n okula gitmek istememesine neden olan sorunla ilgili } \\
\text { çözüm önerileriniz nelerdir?” }\end{array}$ & $\begin{array}{l}\text { 2. 7. sinif, Ana İşsiz } \\
\text { Kalınca, 2. Soru (s. 25). }\end{array}$ \\
\hline
\end{tabular}

\section{Bulgular}

Bu bölümde Türkçe ders kitaplarındaki metni anlama sorularının eleştirel düşünme becerilerine göre dağllımına yönelik bulgulara yer verilmiştir.

Tablo 4. Sınıf seviyesine göre soruların eleştirel düşünme becerilerine göre dağılımına ilişkin betimsel istatistikler

\begin{tabular}{|c|c|c|c|c|c|c|c|c|}
\hline \multirow[t]{2}{*}{ Sinıf Seviyesi } & \multicolumn{2}{|c|}{ 5. Sinif } & \multicolumn{2}{|c|}{ 6. Sinif } & \multicolumn{2}{|c|}{ 7. sinif } & \multicolumn{2}{|c|}{ 8.sinif } \\
\hline & $f$ & $\%$ & $f$ & $\%$ & $f$ & $\%$ & $f$ & $\%$ \\
\hline \multicolumn{9}{|l|}{ İÇERİĞİ ANLAMA } \\
\hline Tanımlama & 85 & 51,2 & 72 & 39,34 & 85 & 39,17 & 113 & 57,95 \\
\hline Yorumlama (ilişki kurma) & 46 & 27,71 & 37 & 20,22 & 43 & 19,82 & 29 & 14,87 \\
\hline Yorumlama (örtük anlam) & 5 & 3,01 & 8 & 4,37 & 9 & 4,15 & 12 & 6,15 \\
\hline Yorumlama (Ana fikir vb.) & o & o & 4 & 2,19 & 6 & 2,76 & 2 & 1,03 \\
\hline \multicolumn{9}{|l|}{ DERİNLEMESİNE ANLAMA } \\
\hline Analiz & o & o & 2 & 1,09 & 2 & 0,92 & o & o \\
\hline Çıkarım & 3 & 1,81 & 1 & 0,55 & 6 & 2,76 & 5 & 2,56 \\
\hline Açıklama & 16 & 9,64 & 39 & 21,31 & 25 & 11,52 & 16 & 8,21 \\
\hline Varsayımda bulunma & o & o & 4 & 2,19 & 13 & 5,99 & 3 & 1,54 \\
\hline Değerlendirme & 11 & 6,63 & 16 & 8,74 & 28 & 12,9 & 15 & 7,69 \\
\hline Toplam & 166 & 100 & 183 & 100 & 217 & 100 & 195 & 100 \\
\hline
\end{tabular}

Tablo 3'e göre metni anlama sorularının eleştirel düşünme becerilerine göre sınıf seviyelerindeki dağılımına bakıldığında farklı beceri alanlarına yönelik soruların aynı sınıf seviyesindeki dağılımının dengeli olmadığı görülmektedir. 5. sınıf seviyesinde en çok tanımlama sorularına $(\% 51,2)$ yer verildiği yorumlama (ana fikir), analiz, varsayımda bulunma becerilerine yönelik sorulara hiç yer verilmediği görülmektedir. 6. sınıf seviyesinde en çok tanımlama sorularına $(\% 39,34)$ yer verildiği yorumlama (ana fikir), analiz, çıkarım, varsayımda bulunma becerilerine yönelik sorulara çok az yer verildiği görülmektedir. 7. sınıf seviyesinde en çok tanımlama sorularına $(\% 39,17)$ yer verildiği yorumlama (ana fikir), analiz, çıkarım becerilerine yönelik sorulara çok az yer verildiği görülmektedir. 8. sınıf

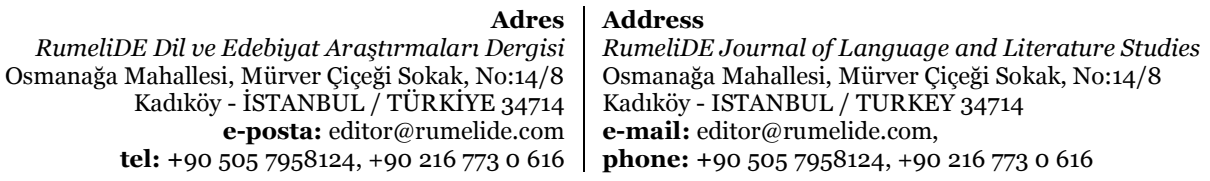


Examining text comprehension questions in Turkish textbooks according to critical thinking skills / F. Amanvermez İncirkuş; K. Özçetin (pp. 290-311)

seviyesinde en çok tanımlama sorularına (\%57, 95) yer verildiği yorumlama (ana fikir), çıkarım, varsayımda bulunma becerilerine yönelik sorulara çok az yer verildiği; analiz becerisine yönelik sorulara hiç yer verilmediği görülmektedir. Tabloya bakıldığında bütün sınıf düzeylerinde tanımlama ve yorumlama (ilişki kurma) düzeylerine yönelik sorulara sıklıkla yer verildiği görülmektedir. Diğer bir deyişle hangi sınıf seviyesinde hangi eleştirel düşünme becerilerinin üzerinde durulacağının belirlenmediği söylenebilir.

Aynı beceri alanına yönelik soruların farklı sınıf seviyesindeki dağılımının dengeli olmadığı görülmektedir. Tanımlama düzeyindeki sorulara 5. sinıflarda \%51,2, 6. sınıflarda \%39, 34, 7. sinıflarda $\% 39,17$, 8. sınıflarda \%57,95 oranında yer verildiği görülmektedir. Değerlendirme düzeyindeki sorulara 5. siniflarda \%6,63, 6. siniflarda $\% 8,74,34$, 7. siniflarda \%12,9, 8. siniflarda \%7,69 oranında yer verildiği görülmektedir. Bu sonuçlardan hareketle metni anlama soruları hazırlanırken eleştirel düşünme becerilerinin öğretilmesinde sınıf seviyesine göre planlama yapılmadığı ve aşamalı bir eğitimin amaçlanmadığı söylenebilir.

Bütün sınıf seviyelerinde içerik bilgisi oluşturmaya yönelik tanımlama ve yorumlama becerilerine yönelik sorulara daha fazla yer verildiği; ancak öğrencilerin içerikten yola çıarak düşünme becerilerini geliştirmeye yönelik analiz, çıkarım, açıklama, varsayımda bulunma ve değerlendirme becerilerine yönelik sorulara çok az yer verildiği ya da hiç yer verilmediği görülmektedir. Dolayısıyla Türkçe ders kitaplarında yer alan metni anlama sorularıyla öğrencileri basit düzeyde düşünmeye yönlendirecek soru tiplerine daha fazla yer verildiği ancak öğrencilerin üst düzey düşünme becerilerini geliştirmelerini sağlayacak sorulara ise gerektiği kadar yer verilmediği söylenebilir.

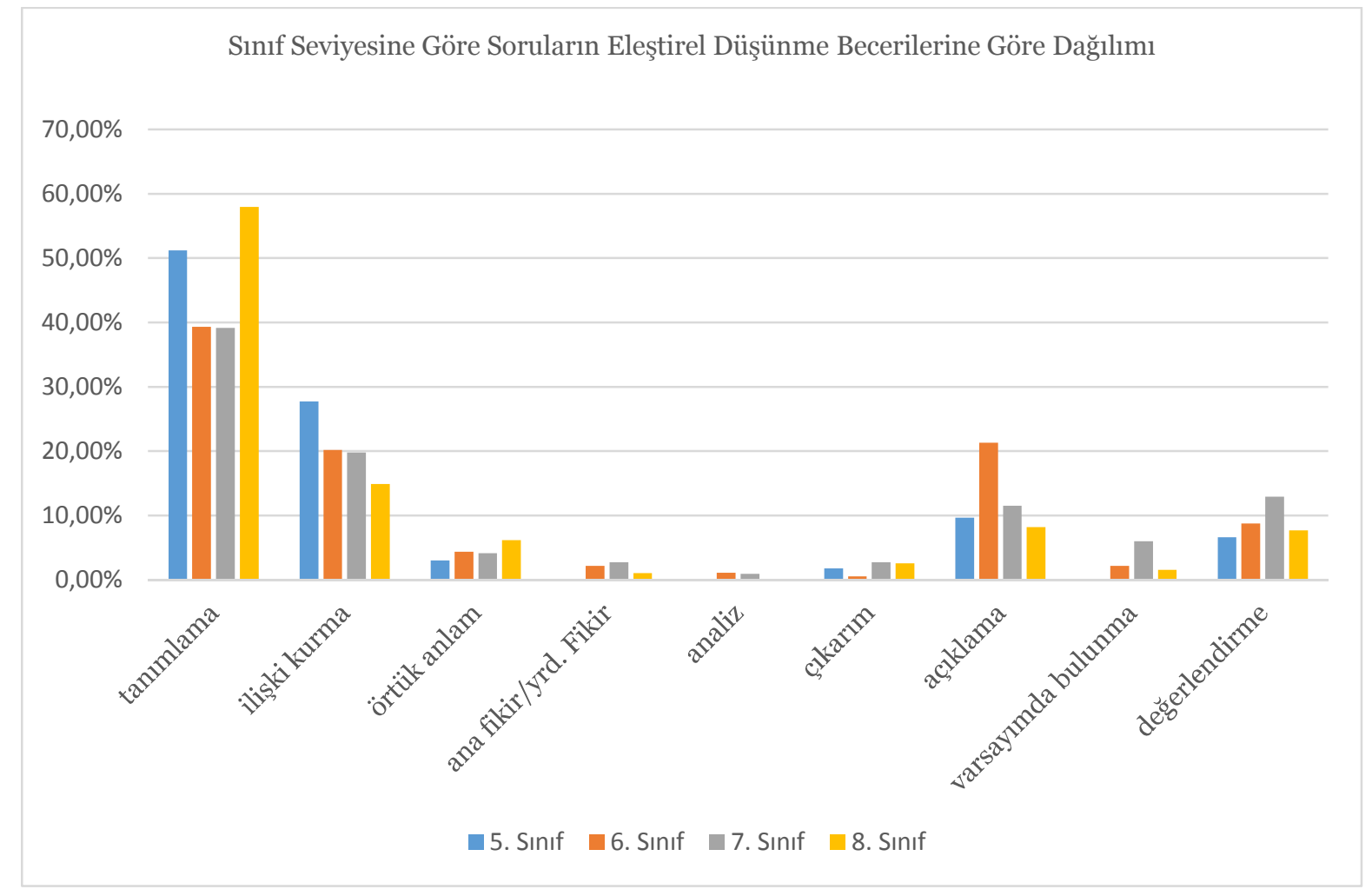

Şekil 1. Soruların eleştirel düşünme becerilerine göre çubuk grafik dağılımı

\begin{tabular}{|c|c|}
\hline Adres & Address \\
\hline RumeliDE Dil ve Edebiyat Araştırmaları Dergisi & RumeliDE Journal of Language and Literature Studies \\
\hline Osmanağa Mahallesi, Mürver Çiçeği Sokak, No:14/8 & Osmanağa Mahallesi, Mürver Çiçeği Sokak, No:14/8 \\
\hline $\begin{array}{r}\text { Kadıköy - İSTANBUL / TÜRKIYE } 34714 \\
\text { e-posta: editor@rumelide.com } \\
\text { tel: +90 } 5057958124,+902167730616\end{array}$ & $\begin{array}{l}\text { Kadıköy - ISTANBUL / TURKEY } 34714 \\
\text { e-mail: editor@rumelide.com, } \\
\text { phone: +90 505 7958124, +90 } 216773 \text { o } 616\end{array}$ \\
\hline
\end{tabular}




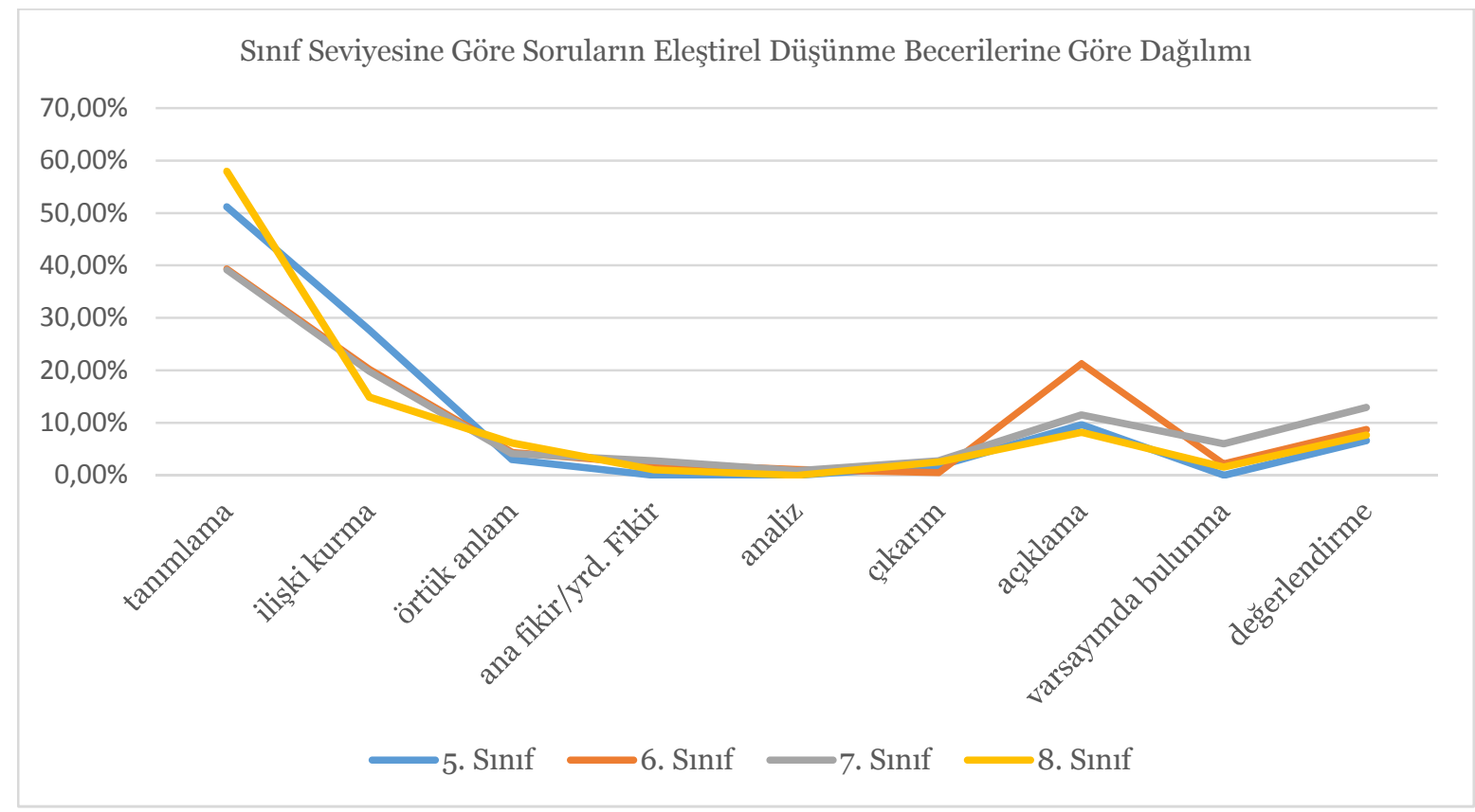

Şekil 2. Soruların eleştirel düşünme becerilerine göre çizgi grafik dağılımı

1. ve 2. şekiller incelendiğinde soruların eleştirel düşünme becerilerine göre dağılımının bütün sınıf düzeylerinde benzerlik gösterdiği görülmektedir. Bütün sınıf düzeylerinde basit düşünme becerilerine yönelik sorulara; üst düzey düşünme becerileri gerektiren sorulardan daha fazla yer verildiği görülmektedir. Cevabı metinde bulunan içeriği anlamaya yönelik becerilerden tanımlama becerisine yorumlama becerisinden daha fazla yer verildiği; cevabı metinde bulunmayan derinlemesine anlama sorularından ise analiz ve değerlendirme sorularına kısmen yer verildiği ancak analiz, çıkarım, varsayımda bulunma sorularına ise neredeyse hiç yer verilmediği görülmektedir.

Tablo 5. Metin türüne göre soruların eleştirel düşünme becerilerine göre dağılımına ilişkin betimsel istatistikler

\begin{tabular}{|c|c|c|c|c|c|c|c|c|}
\hline \multirow[t]{2}{*}{ Metin Türü İstatistikler } & \multicolumn{2}{|c|}{ Öyküleyici } & \multicolumn{2}{|c|}{ Bilgilendirici } & \multicolumn{2}{|c|}{ Şiir } & \multicolumn{2}{|c|}{ Toplam } \\
\hline & $\mathbf{f}$ & $\%$ & $\mathbf{f}$ & $\%$ & $\mathbf{f}$ & $\%$ & $\mathbf{f}$ & $\%$ \\
\hline Toplam metin sayısı & 60 & 46,8 & 49 & 38,28 & 19 & 14,84 & 128 & 100 \\
\hline İçeriği Anlama & 255 & 68,91 & 224 & 76,71 & 77 & 77,77 & 556 & 73,06 \\
\hline Derinlemesine Anlama & 115 & 31,08 & 68 & 23,2 & 22 & 22,22 & 205 & 26,9 \\
\hline Toplam & 370 & 100 & 292 & 100 & 99 & 100 & 761 & 100 \\
\hline Tanimlama & 151 & 40,8 & 163 & 55,8 & 41 & 41,4 & 355 & 46,64 \\
\hline Yorumlama (ilişki kurma) & 89 & 24,05 & 50 & 17,1 & 16 & 16,16 & 155 & 20,36 \\
\hline Yorumlama (örtük anlam) & 8 & 2,16 & 9 & 3,08 & 17 & 17,17 & 34 & 4,46 \\
\hline Yorumlama (Ana fikir/yardımcı fikir) & 7 & 1,89 & 2 & 0,68 & 3 & 3,03 & 12 & 1,57 \\
\hline Analiz & 2 & 0,54 & 2 & 0,68 & o & o & 4 & 0,52 \\
\hline Çıkarım & 9 & 2,43 & 4 & 1,36 & 2 & 2,02 & 15 & 1,9 \\
\hline Açılklama & 45 & 12,1 & 38 & 13,01 & 13 & 13,13 & 96 & 12,61 \\
\hline Varsayımda bulunma & 16 & 4,32 & 3 & 1,02 & 1 & 1,01 & 20 & 2,62 \\
\hline Değerlendirme & 43 & 11,6 & 21 & 7,19 & 6 & 6,06 & 70 & 9,1 \\
\hline Toplam & 370 & 100 & 292 & 100 & 99 & 100 & 761 & 100 \\
\hline
\end{tabular}


Examining text comprehension questions in Turkish textbooks according to critical thinking skills / F. Amanvermez İncirkuş; K. Özçetin (pp. 290-311)

Tablo 5’e bakıldığında metin türleri içerisinde en yüksek oranda $(\% 46,8)$ öyküleyici metinlere yer verildiği görülmektedir. Yine metin türlerine göre Türkçe ders kitaplarında yer alan soru sayılarının toplamına bakıldığında en fazla sorunun öyküleyici metinlerde (370) sorulduğu görülmektedir. Metni anlama sorularına dayalı eleştirel düşünme boyutlarına bakıldığında üç metin türünde de yüksek oranda $(\% 73,06)$ içeriği anlamaya yönelik sorulara; derinlemesine anlamaya yönelik sorulardan $(\% 26,9)$ daha fazla yer verildiği görülmektedir.

Eleştirel düşünme becerileri açısından metin türlerine göre içeriği anlamaya yönelik soruların dağılımına bakıldığında her üç metin türünde de en çok basit düzey düşünme gerektiren bilgi isteyen/metinde cevabı doğrudan bulunan tanımlama becerisine $(\% 46,64)$ yönelik sorulara yer verildiği görülmektedir. İkinci olarak yine metinde cevabı bulunan ilişki kurma, karşılaştırma, benzerlik ve farklılıkları bulma gibi yorumlamaya dayalı sorulara $(\% 20,36)$ yer verildiği görülmektedir. Ancak metinle ilişkili öğrencinin metni anlayarak cevaplayabileceği örtük anlam $(\% 4,46)$ ve ana fikir bulmayı $(\% 1,57)$ amaçlayan yorumlama sorularına çok az yer verilmiştir.

Eleştirel düşünme becerileri açısından metin türlerine göre derinlemesine anlamaya yönelik soruların dağılımına bakıldığında her üç metin türünde de üst düzey düşünme gerektiren sorulardan en çok açıllama $(\% 12,61)$ becerisine yönelik sorulara yer verildiği görülmektedir. Ancak bu oran toplamdaki soru sayısı içerisinde düşüktür. İkinci olarak değerlendirme $(\% 9,1)$ becerisine yönelik sorulara yer verildiği görülmektedir. Analiz, çıkarım, varsayımda bulunma becerilerine yönelik sorulara neredeyse hiç yer verilmediği görülmektedir. Yani metin türlerine göre soruların eleştirel düşünme becerilerine dağılımına bakıldığında her üç metin türünde de en çok içeriği anlamaya yönelik tanımlama ve yorumlama (ilişki kurma, karşllaştırma vb.) becerisindeki sorulara yer verildiği; derinlemesine anlamaya yönelik sorulara çok az yer verildiği ya da hiç yer verilmediği görülmektedir.

Tablo 6. Bilgilendirici metin türüne göre farklı sınıf seviyelerinde soruların eleştirel düşünme becerilerine göre dağılımına ilişkin betimsel istatistikler

\begin{tabular}{|c|c|c|c|c|c|c|c|c|c|c|c|}
\hline & \multirow{3}{*}{$\begin{array}{l}\text { Metin Türü } \\
\text { Sinıf Seviyesi }\end{array}$} & \multicolumn{10}{|c|}{ Bilgilendirici Metinler } \\
\hline & & \multicolumn{2}{|l|}{5.} & \multicolumn{2}{|l|}{6.} & \multicolumn{2}{|l|}{7.} & \multicolumn{2}{|l|}{8.} & \multicolumn{2}{|c|}{ Toplam } \\
\hline & & $\mathbf{f}$ & $\%$ & $\mathbf{f}$ & $\%$ & $\mathbf{f}$ & $\%$ & $\mathbf{f}$ & $\%$ & $\mathbf{f}$ & $\%$ \\
\hline & Metin sayısı & 11 & 22,44 & 14 & 28,57 & 12 & 24,48 & 12 & 24,48 & 49 & 100 \\
\hline \multirow{4}{*}{ 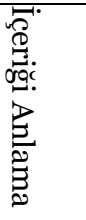 } & Tanımlama & 38 & 58,46 & 44 & 50,57 & 38 & 46,91 & 43 & 72,88 & 163 & 55,82 \\
\hline & Yorumlama (ilişki kurma) & 19 & 29,23 & 13 & 14,94 & 14 & 17,28 & 4 & 6,78 & 50 & 17,12 \\
\hline & Yorumlama (örtükanlam) & $\mathrm{o}$ & $\mathrm{O}$ & 4 & 4,6 & 4 & 4,94 & 1 & 1,69 & 9 & 3,08 \\
\hline & Yorumlama (Ana fikir vb.) & o & o & 1 & 1,15 & 1 & 1,23 & o & o & 2 & 0,68 \\
\hline \multirow{6}{*}{ 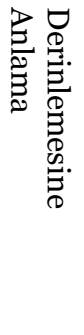 } & Analiz & $\mathrm{O}$ & o & 1 & 1,15 & 1 & 1,23 & o & o & 2 & 0,68 \\
\hline & Çıkarım & 2 & 3,08 & 1 & 1,15 & 1 & 1,23 & $\mathrm{O}$ & o & 4 & 1,36 \\
\hline & Açılama & 3 & 4,62 & 15 & 17,24 & 13 & 16,5 & 7 & 11,86 & 38 & 13,01 \\
\hline & Varsayımda bulunma & o & o & 1 & 1,15 & 2 & 2,47 & o & o & 3 & 1,02 \\
\hline & Değerlendirme & 3 & 4,62 & 7 & 8,05 & 7 & 8,64 & 4 & 6,78 & 21 & 7,19 \\
\hline & Toplam & 65 & 22,26 & 87 & 29,79 & 81 & 27,7 & 59 & 20,2 & 292 & 100 \\
\hline
\end{tabular}

Tablo 6'da bilgilendirici metinlerin farklı sınıf seviyelerindeki dağılımının benzer olduğu görülmektedir. Sınıflara göre karşllaştırma yapıldığında eleştirel düşünme becerilerine yönelik soruların dağılımında 5. sınıftan 8. sınıfa doğru gidildikçe sınıf seviyesine göre aşamalılık

\begin{tabular}{|c|c|}
\hline & \\
\hline alarn $D$ & d Literatur \\
\hline $\mathrm{Mal}$ & Mahallesi, Mürver Çiçeği Sokak, No:14/8 \\
\hline Kadıköy & STANBUL / TURKEY 34714 \\
\hline $\begin{array}{r}\text { e-posta: edito } \\
\text { tel: }+905057958124,+\end{array}$ & $\begin{array}{l}\text { editor@rumelide.com, } \\
\text { +90 505 7958124, +90 } 216773 \text { o } 616\end{array}$ \\
\hline
\end{tabular}


görülmemektedir. Soruların beceriler açısından dağılımı 5 ve 8. sınıflarda benzerdir. Cevabı doğrudan metinde bulunan tanımlama becerisine yönelik sorulara en çok 8. sinıflarda yer verilmiştir $(\% 72,88)$. 5. sinıflarda örtük anlam, ana fikir bulma, analiz, varsayımda bulunma gibi becerilere yönelik sorulara hiç yer verilmemiştir. 8. sınıflarda da öğrencilerin metin hakkında düşünerek kendi düşünceleriyle cevap verebileceği ana fikir bulma, analiz, çıkarım, varsayımda bulunma gibi becerilere yönelik sorulara yer verilmediği görülmektedir ( 5 ve 8 . sinıflarda ders kitapları incelendiğinde ana fikir bulma, varsayımda bulunma gibi becerilere yönelik ayrı etkinlik uygulamalarına rastlanmıştır). 6 ve 7 . sınıflarda da en çok tanımlama becerisine $(6: \% 50,57 ; 7: \% 46,91)$ yönelik sorulara yer verilmiştir. Derinlemesine anlama gerektiren analiz, çıkarım, açıklama, varsayımda bulunma, değerlendirme türündeki sorulara çok az yer verilmiştir ve sınıf seviyesine göre soruların dağılımında bir aşamalılık bulunmamaktadır.

Başka bir deyişle Türkçe ders kitaplarında bilgilendirici metin türünde sorular hazırlanırken bu sorular aracılığıyla eleştirel düşünme becerilerini geliştirmeye yönelik sınıf düzeyine göre öğretilecek/üzerinde durulacak becerilerin belirlenmediği söylenebilir. Eleştirel düşünmede soru sormak ve soruları cevaplamak önemli bir adım olsa da soruların planlı bir şekilde eleştirel düşünme becerisi için bir araç olarak kullanılmadığı görülmektedir.

Tablo 7. Öyküleyici metin türüne göre farklı sınıf seviyelerinde soruların eleştirel düşünme becerilerine göre dağılımına ilişkin betimsel istatistikler

\begin{tabular}{|c|c|c|c|c|c|c|c|c|c|c|c|}
\hline & \multirow{3}{*}{$\begin{array}{l}\text { Metin Türü } \\
\text { Sınıf Seviyesi }\end{array}$} & \multicolumn{10}{|c|}{ Öyküleyici Metinler } \\
\hline & & \multicolumn{2}{|l|}{5} & \multicolumn{2}{|l|}{6} & \multicolumn{2}{|l|}{7} & \multicolumn{2}{|l|}{8} & \multicolumn{2}{|c|}{ Toplam } \\
\hline & & $\mathbf{f}$ & $\%$ & $\mathbf{f}$ & $\%$ & $\mathbf{f}$ & $\%$ & $\mathbf{f}$ & $\%$ & $\mathbf{f}$ & $\%$ \\
\hline & Metin sayısı & 15 & 25 & 14 & 23,3 & 17 & 28,3 & 14 & 23,3 & 60 & 100 \\
\hline \multirow{4}{*}{ 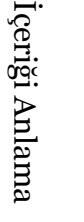 } & Tanimlama & 32 & 42,6 & 22 & 28,9 & 42 & 35,89 & 55 & 53,92 & 151 & 40,8 \\
\hline & Yorumlama (ilişki kurma) & 23 & 30,6 & 21 & 27,6 & 26 & 22,22 & 19 & 18,62 & 89 & 24,05 \\
\hline & Yorumlama (örtükanlam) & 1 & 1,33 & 1 & 1,31 & 3 & 2,56 & 3 & 2,94 & 8 & 2,16 \\
\hline & Yorumlama (Ana fikir) & o & o & 3 & 3,94 & 3 & 2,56 & 1 & 0,98 & 7 & 1,89 \\
\hline \multirow{6}{*}{ 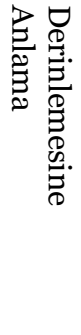 } & Analiz & $\mathrm{O}$ & 0 & 1 & 1,31 & 1 & 0,85 & o & o & 2 & 0,54 \\
\hline & Çıkarım & 1 & 1,33 & o & $\mathrm{O}$ & 3 & 2,56 & 5 & 4,9 & 9 & 2,43 \\
\hline & Açılklama & 11 & 14,6 & 16 & 21,05 & 11 & 9,4 & 7 & 6,86 & 45 & 12,1 \\
\hline & Varsayımda bulunma & o & o & 3 & 3,94 & 10 & 8,54 & 3 & 2,94 & 16 & 4,32 \\
\hline & Değerlendirme & 7 & 9,33 & 9 & 11,84 & 18 & 15,3 & 9 & 8,82 & 43 & 11,6 \\
\hline & Toplam & 75 & 100 & 76 & 100 & 117 & 100 & 102 & 100 & 370 & 100 \\
\hline
\end{tabular}

Tablo 7’ye bakıldığında öyküleyici metinlerin farklı sınıf seviyelerindeki dağılımının benzer olduğu görülmektedir. Sinıflara göre karşllaştırma yapıldığında eleştirel düşünme becerilerine yönelik soruların dağılımında 5 . sinıftan 8 . sınıfa doğru gidildikçe sınıf seviyesine göre artan aşamalı bir dağılım görülmemektedir.

Soruların beceriler açısından dağılımı benzerdir. Bütün sınıf düzeylerinde en çok cevabı doğrudan metinde bulunan tanımlama becerisine yönelik sorulara yer verilmiştir $(\% 40,8)$. İkinci olarak yine cevabı metinde bulunan yorumlama (ilişki kurma) becerisine yönelik sorular sorulmuştur $(\% 24,05)$. 
Examining text comprehension questions in Turkish textbooks according to critical thinking skills / F. Amanvermez İncirkuş; K. Özçetin (pp. 290-311)

Öyküleyici metin türünde de bilgilendirici metinlerde olduğu gibi (bkz. tablo 6.) öğrencinin metni anlayarak ya da kendi deneyim ve düşünceleriyle cevap vermesini gerektiren ana fikir, analiz, çıkarım, varsayımda bulunma gibi sorulara çok az yer verilmiştir. Farklı sınıf seviyelerinde bu soruların dağılımında bir aşamalılık bulunmamaktadır. Derinlemesine anlama gerektiren sorulara bütün sınıf seviyelerinde sıklıkla açıklama $(\% 12,1)$ ve değerlendirme $(\% 11,6)$ becerisine yönelik sorulara yer verilmiştir. Türkçe ders kitaplarında öyküleyici metin türünde sorular hazırlanırken bu sorular aracllığıyla eleştirel düşünme becerilerini geliştirmeye yönelik sınıf düzeyine göre öğretilecek/üzerinde durulacak becerilerin belirlenmediği söylenebilir.

Tablo 8. Şiir metinlerine göre farklı sınıf seviyelerinde soruların eleştirel düşünme becerilerine göre dağılımına ilişkin betimsel istatistikler

\begin{tabular}{|c|c|c|c|c|c|c|c|c|c|c|c|}
\hline & Metin Türü & Şii & Meti & leri & & & & & & & \\
\hline & Sinıf Seviyesi & 5. & & 6. & & 7. & & 8. & & To & \\
\hline & & f & $\%$ & $\mathbf{f}$ & $\%$ & $\mathbf{f}$ & $\%$ & f & $\%$ & $\mathbf{f}$ & $\%$ \\
\hline & Metin sayısı & 6 & 31,57 & 4 & 21,05 & 3 & 15,78 & 6 & 31,57 & 19 & 100 \\
\hline 赵 & Tanımlama & 15 & 57,6 & 6 & 30 & 5 & 26,31 & 15 & 44,11 & 41 & 41,41 \\
\hline 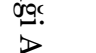 & Yorumlama (ilişki kurma) & 4 & 15,38 & 3 & 15 & 3 & 15,78 & 6 & 17,64 & 16 & 16,16 \\
\hline Е્犬 & Yorumlama (örtük anlam) & 4 & 15,38 & 3 & 15 & 2 & 10,52 & 8 & 23,52 & 17 & 17,17 \\
\hline & Yorumlama (Ana fikir/yardımcı fikir) & o & o & o & o & 2 & 10,52 & 1 & 2,94 & 3 & 3,03 \\
\hline 胥兽. & Analiz & o & o & o & o & o & o & o & o & o & o \\
\hline$\overline{\mathrm{d}}$ & Çıarım & o & o & o & o & 2 & 10,52 & o & o & 2 & 2,02 \\
\hline$g$ & Açıklama & 2 & 7,69 & 8 & 40 & 1 & 5,26 & 2 & 5,88 & 13 & 13,13 \\
\hline$\theta$ & Varsayımda bulunma & o & o & o & o & 1 & 5,26 & o & o & 1 & 1,01 \\
\hline & Değerlendirme & 1 & 3,84 & o & o & 3 & 15,78 & 2 & 5,88 & 6 & 6,06 \\
\hline & Toplam & 26 & 100 & 20 & 100 & 19 & 100 & 34 & 100 & 99 & 100 \\
\hline
\end{tabular}

Tablo 8'e bakıldığında şiir metinlerinin farklı sınıf seviyelerindeki dağılımının benzer olduğu görülmektedir. Sınıflara göre karşılaştırma yapıldığında eleştirel düşünme becerilerine yönelik soruların dağılımında 5. sınıftan 8. sınıfa doğru gidildikçe sınıf seviyesine göre artan aşamalı bir dağılım görülmemektedir. Bütün sınıf seviyelerinde içeriği anlamaya yönelik basit düşünme gerektiren sorulara yer verildiği görülmektedir. Türkçe ders kitaplarında şiir metinlerinde sorular hazırlanırken bu sorular aracıllğıyla eleştirel düşünme becerilerini geliştirmeye yönelik sinıf düzeyine göre öğretilecek/üzerinde durulacak becerilerin belirlenmediği söylenebilir.

Soruların beceriler açısından dağılımı benzerdir. Bütün sınıf düzeylerinde en çok cevabı doğrudan metinde bulunan tanımlama becerisine yönelik sorulara yer verilmiştir (\%41,41). İkinci olarak yine cevabı metinde bulunan yorumlama (ilişki kurma) becerisine yönelik sorular sorulmuştur $(\% 16,16)$. Bilgilendirici ve öyküleyici metinlerde örtük anlam sorularına pek yer verilmezken şiir metinlerinde metin türünden kaynaklı olarak örtük anlam sorularına $(\% 17,17)$ da yer verildiği söylenebilir.

Şiir metinlerinde de bilgilendirici ve öyküleyici metinlerde olduğu gibi (bkz. tablo 6 ve 7) öğrencinin metni anlayarak ya da kendi deneyim ve düşünceleriyle cevap vermesini gerektiren ana fikir, analiz, çıkarım, varsayımda bulunma, açılama, değerlendirme gibi sorulara çok az yer verilmiştir ya da hiç yer verilmemiştir.

\begin{tabular}{|c|c|}
\hline & \\
\hline alarn $D$ & d Literatur \\
\hline $\mathrm{Mal}$ & Mahallesi, Mürver Çiçeği Sokak, No:14/8 \\
\hline Kadıköy & STANBUL / TURKEY 34714 \\
\hline $\begin{array}{r}\text { e-posta: edito } \\
\text { tel: }+905057958124,+\end{array}$ & $\begin{array}{l}\text { editor@rumelide.com, } \\
\text { +90 505 7958124, +90 } 216773 \text { o } 616\end{array}$ \\
\hline
\end{tabular}




\section{Sonuç ve tartışma}

Eleştirel düşünme becerilerinin geliştirilmesinde soru sormak önemlidir çünkü eleştirel düşünme soru sormayla başlar (Nosich, 2015). Bu bakımdan büyük oranda metni anlama ve değerlendirme ekseninde sürdürülen Türkçe derslerinde sorulan/hazırlanan soruların niteliği her sınıf seviyesinde öğrencilerin düşünme becerilerinin geliştirilmesi açısından önemlidir. Türkçe 5-8. sınıf ders kitaplarında yer alan metni anlama ve değerlendirme sorularının eleştirel düşünme becerilerine göre incelendiği bu çalışmada artan sınıf seviyesine göre soruların becerilere yönelik dağllımında farklılık olmadığı görülmektedir. Bütün sınıf seviyelerinde içerik bilgisi oluşturmaya yönelik tanımlama ve yorumlama becerilerine yönelik sorulara daha fazla yer verildiği; ancak üst düzey düşünme becerilerini geliştirmeye yönelik analiz, çıkarım, açıklama, varsayımda bulunma ve değerlendirme becerilerine yönelik sorulara çok az yer verildiği ya da hiç yer verilmediği görülmektedir. Türkçe 5 -8. sınıf ders kitaplarında yer alan soruların eleştirel düşünme becerine göre dağılımı bilgilendirici, öyküleyici ve şiir metin türüne göre değerlendirilmiştir. Her üç metin türünde de en çok içeriği anlamaya yönelik tanımlama ve yorumlama (ilişki kurma, karşlaştırma vb.) becerisindeki sorulara yer verildiği; derinlemesine anlamaya yönelik analiz, açıklama, varsayımda bulunma, çıkarım ve değerlendirmeye yönelik sorulara çok az yer verildiği ya da hiç yer verilmediği görülmektedir. Yani metin türü özelinde üzerinde durulan eleştirel düşünme becerisi bulunmamaktadır.

Aynı metin türünde yer alan soruların farklı sınıf seviyelerindeki dağılımına ayrı ayrı bakıldığında da bütün sınıf seviyelerinde öyküleyici, bilgilendirici ve şiir türündeki metinlerde artan sinıf seviyesinde metin türüne özgü bir değişiklik görülmemiştir. 5. sınıftan 8. sınıfa doğru gidildiğinde bütün sınıf seviyelerinde ve metin türlerinde tanımlama ve ilişki kurmaya yönelik yorumlama becerisine yönelik sorulara yer verildiği görülmektedir. Ancak öğrencinin metni anlayarak ya da kendi deneyim ve düşünceleriyle cevap vermesini gerektiren ana fikir, analiz, çıkarım, varsayımda bulunma, açıklama, değerlendirme becerilerine yönelik sorulara çok az yer verilmiştir ya da hiç yer verilmemiştir.

Elde edilen bu sonuç dikkate alındığında her üç yılda bir ortaokul eğitiminin sonunda OECD’ye (Ekonomik İşbirliği ve Kalkınma Örgütü) üye ülkelerde gerçekleştirilen PISA (Uluslararası Öğrenci Değerlendirme Programı) sınavının sonuçlarının ülkemiz açısından şaşırtıcı olmadığı söylenebilir. PISA'da temel amaç öğrencilerin okulda kazandıkları bilgi ve becerileri gerçek hayatta ne oranda uygulayabildiklerini belirleyebilmektir (MEB, 2019b). Bu sinav aracıllğıyla ülkelerin toplumsal ve ekonomik kalkınmasına katkı sağlayacak üst düzey düşünme becerileri gelişmiş öğrenci oranını (5-6. yeterlik alanı) belirlemek amaçlanmaktadır. PISA'da öğrenciler için okuma becerisinde 1'den 6'ya kadar yeterlik alanları belirlenmiştir. Bu alanlara karşılık gelen sorular aracılı̆̆ıyla okuma açısından öğrencilerin neleri başarıp başaramadığı belirlenmeye çalışılmıştır.

1. yeterlik alanında öğrenciler, aşina oldukları kısa bir metin türünde açıkça sunulan bilgileri bulup bunları anlayabilir; 2. yeterlik alanında orta uzunlukta bir metinde, metinde açıkça sunulması hâlinde metnin genel amacını, ana fikrini ve metinde yer alan ilişkileri anlayabilir; 3. yeterlik alanında metinde açıkça belirtilmese de metnin genel amacını anlayabilir, metnin farklı yerlerindeki bilgileri bir araya getirerek çıkarım yapabilir. Çok uzun olmayan metinlerin ana fikrini bulabilir. 4, 5 ve 6. yeterlik alanındaki öğrenciler ise çeşitli dış ölçütler kullanarak bir metni derinlemesine değerlendirebilir, hipotezler oluşturabilir, ipuçlarından yola çıkarak objektif değerlendirmeler yapabilir, birden çok metinde yer alan uzun paragrafları anlayarak farklı bakış açıları geliştirebilir ve sonuç çıkarabilir. Başka bir deyişle karmaşı ve uzun metinleri anlayarak eleştirel bir bakış açısıyla değerlendirebilirler. Son yapılan PISA sınavlarına (MEB, 2013, 2016, 2019) bakıldığında Türkiye'de en çok 1 ve 2. yeterlik

RumeliDE Dil ve Edebiyat Araștırmaları Dergisi Osmanağa Mahallesi, Mürver Ciçeği Sokak, No:14/8 Kadıköy - ISTANBUL / TÜRKIYE 34714 e-posta: editor@rumelide.com tel: +90 $5057958124,+902167730616$
Address

RumeliDE Journal of Language and Literature Studies

Osmanağa Mahallesi, Mürver Çiçeği Sokak, No:14/8

Kadıköy - ISTANBUL / TURKEY 34714

e-mail: editor@rumelide.com,

phone: +90 505 7958124, +90 2167730616 
Examining text comprehension questions in Turkish textbooks according to critical thinking skills / F. Amanvermez İncirkuş; K. Özçetin (pp. 290-311)

alanında öğrenci bulunmaktadır. Bu sonucun ortaya çımasında öğretmen, öğrenci, aile, öğretim materyali-tekniği vb. farklı değişkenler etkili olmuş olabilir. Bu çalışmadan elde edilen sonuçlar dikkate alındığında öğrencilerin temel ders materyallerinden biri olan Türkçe ders kitaplarında (5-8. sınıf) içeriği anlamaya yönelik, cevabı metinde bulunan tanımlama ve basit düzey ilişki kurmayı sağlayan yorumlama düzeyindeki sorulara yer verildiği görülmektedir. Bu soru tiplerinin de PISA sınavlarındaki 1. ve 2. düzey yeterlik alanına denk geldiği söylenebilir. Başka bir deyişle öğrencilerin başarı oranının uluslararası sınavlarda temel yeterlik alanlarında (1 ve 2. düzey) yoğunlaşmış olmasının sebeplerinden birinin 5-8. sınıfı kapsayan eğitim sürecinde, bu çalışmada metni derinlemesine anlamayı sağlayan analiz, çıkarım, açıklama, varsayımda bulunma ve değerlendirme becerilerine yönelik; PISA'da ise 4, 5 ve 6. düzey yeterlik alanlarına karşıllk gelen açı uçlu problemlerle/sorularla karşılaşmamış olmalarından kaynaklandığı söylenebilir. Dolayısıyla her ne kadar Türkçe öğretim programında eleştirel düşünme, üst düzey düşünme, yaşam boyu öğrenme kavramlarına vurgu yapılsa da çoğunlukla okumaya ve anlamaya dayalı Türkçe derslerinde ders kitaplarının/içeriklerinin bu becerileri destekleyecek şekilde yapılandırılmadığı söylenebilir. Öğrenciler ortaokul süreci boyunca okuma becerileri açısından basit düzeyde içeriği anlamaya yönelik bir eğitim almaktadır ve bunun bir çıktısı olarak da yapılan uluslararası sınavlarda aldıkları eğitime karşllık gelen 1 ve 2. yeterlik düzeyinde performans göstermektedir.

Öğrencilerin eleştirel düşünme düzeylerini inceleyen çalışmalar incelendiğinde, ortaokul düzeyinde yapılan çalışmalar sınırlıdır. Özdemir (2005) üniversite öğrencilerinin eleştirel düşünme becerisi bakımından orta düzeyde oldukları sonucuna ulaşmıştır. Demir (2006), ilköğretim 4. ve 5. sınıf öğrencilerinin sosyal bilgiler derslerinde eleştirel düşünme düzeylerini çeşitli değişkenler açısından incelediği çalışmasında öğrencilerin genel olarak yüksek düzey eleştirel düşünme becerilerine sahip oldukları sonucuna ulaşmıştır. Korkmaz ve Yeşil (2009); ilköğretim, ortaöğretim ve yükseköğretim düzeyi son dönemlerinde bulunan öğrencilerin eleştirel düşünme eğilim ve düzeylerinin "orta" düzeyde olduğu; ortaöğretim düzeyinde alınan eğitimin öğrencilerin eleştirel düşünme eğilim ve düzeylerini olumsuz etkilediği; yükseköğretimin ise olumlu katkılar sağladığı sonuçlarına ulaşmışlardır. Altan (2020) beşinci sınıfta okuyan öğrencilerin eleştirel düşünme becerileri puanlarının, altıncı ve yedinci sınıfa devam eden öğrencilerin eleştirel düşünme becerileri puanlarına göre daha düşük olduğu sonucuna ulaşmıştır. Ay ve Akgöl (2008, s. 73 ) yaş ilerledikçe öğrencilerin eleştirel düşünme güçlerinde artış görüldügünü, 16 yaş grubundaki öğrencilerin 17 ve 18 yaş grubundaki öğrencilere göre eleştirel düşünme gücü açısından daha yetersiz olduğunu belirtmişlerdir (Ay ve Akgöl, 2008). Öğrencilerin eleştirel düşünme düzeyleri ile ilgili elde edilen sonuçlar, kullanılan ölçek, örneklem vb. faktörlere göre değişmekle birlikte yaş düzeyinin artmasıyla eleştirel düşünme düzeylerinin arttığı yönünde sonuçlar ağırlıklıdır. Dolayısıyla ortaokul öğrencilerinin 5 . sinıftan 8 . sinıfa kadar seviyesine kadar sistematik bir şekilde artan eleştirel düşünme etkinlikleriyle karşılaşmaları beklenir. Bu nedenle sınıf seviyeleri arttıkça metni anlama sorularının da eleştirel düşünme becerilerine göre sistematik bir şekilde artması gerektiği söylenebilir. Ancak mevcut durumda Türkçe ders kitaplarında yer alan metni anlama sorularının eleştirel düşünme becerilerine göre dağılımında artan sınıf seviyesine göre aşamalı bir değişim görülmemektedir. Bu da metni anlama soruları hazırlanırken eleştirel düşünme becerilerinin öğretilmesinde/geliştirilmesinde sınıf seviyesine göre planlı ve aşamalı bir eğitim yapılmadığını göstermektedir.

Metin türlerine göre soruların eleştirel düşünme becerilerine göre dağılımına bakıldığında hem genel olarak hem de farklı sınıf seviyelerinde bilgilendirici, öyküleyici ve şiir metin türünü dikkate alan bir dağılım olmadığı görülmektedir. Bütün sınıf seviyelerinde ve bütün metin türlerinde sorular tanımlama ve yorumlama becerilerinde yoğunlaşmakta ve benzer şekilde dağılım göstermektedir. Üst

\footnotetext{
\begin{tabular}{r|l} 
Adres & Address \\
RumeliDE Dil ve Edebiyat Araşttrmalar Dergisi & RumeliDE Journal of Language and Literature Studies
\end{tabular} Osmanağa Mahallesi, Mürver Çiçeği Sokak, No:14/8 Osmanağa Mahallesi, Mürver Çiçeği Sokak, No:14/8 Kadıköy - İSTANBUL / TÜRKIYE 34714 Kadıköy - ISTANBUL / TURKEY 34714 e-posta: editor@rumelide.com e-mail: editor@rumelide.com tel: +90 505 7958124, +90 2167730616 phone: +90 505 7958124, +90 2167730616
} 
düzey düşünme gerektiren analiz, çıkarım, açıklama, varsayımda bulunma ve değerlendirme gibi becerilere ise yeteri kadar yer verilmemiştir. Dickson, Simmons ve Kameenui (1998) okuma görevlerinin tam ve doğru olarak yerine getirilmesiyle öğrencilerin metin yapısına ilişkin farkındalığı arasında pozitif bir ilişkinin varlığından bahsetmektedir. Öğrenciler küçük yaşlardan itibaren öyküleyici metin yapısına aşina olduklarından yeni bir beceri öğretilirken açıklama metinlerinden ziyade öyküleyici metin yapılarının kullanılmasının yerinde olacağı söylenebilir. Eleştirel düşünme becerilerine bütün sinıf seviyelerinde yer verilmesi gerekse de örneğin 5 . ve 6 . sinıflarda öyküleyici metinlerde tanımlama, yorumlama, açıklama ve varsayımda bulunma becerileri üzerinde durulurken; 7. ve 8. sinıflarda bu becerilere ek olarak analiz, çıarım, değerlendirme becerilerini geliştirmeye yönelik bir öğretim içeriği oluşturulabilir. Bilgilendirici metinlerde de 5. sinıftan 8. sinıfa doğru gidildikçe tanımlama ve yorumlama sorularından analiz, çıkarım, değerlendirme sorularına doğru aşamalı ve basitten karmaşığa doğru bir sıralama oluşturulabilir. Çünkü ders kitapları incelenirken metni derinlemesine anlamaya yönelik açıklama ve değerlendirme sorularına yer verildiği görülse de bu soruların basit düzeyde, öğrencilerin gerçek hayat problemleriyle ilgili farkındalığını oluşturmayan sorular olduğu söylenebilir.

Soru sormak eleştirel düşünme becerilerinin geliştirilmesinde ve öğretilmesinde önemli olsa da öğrencilerin eleştirel düşünme becerilerini geliştirmek için tek başına yeterli değildir (Ennis, 1993). En nitelikli sorular hazırlanmış olsa da eğer öğrencinin konuyla ilgili içerik bilgisi yoksa konuyla ilgili bakış açısı sergileyemeyecektir. Bundan dolayı eleştirel düşünme eğitiminde öğretmenler öğrencilere nasıl düşünmeleri gerektiğini öğretirken uygun yöntem ve tekniklerle içerik bilgisini oluşturmalı, sinıf içi etkileşimi sağlayan uygulamalar yaptırmalıdır (Willingham, 2007; Schmit, 2002). Eleştirel düşünme becerilerini, eğilimlerini geliştirmek için hazırlanan öğretim programları/ders içerikleri bu anlayışla hazırlanmalıdır. Yapılan çalışmalar da dersin içeriğine uygun strateji yöntem ve tekniklerle yapılandırılmış, hangi disiplinde hangi becerilerin önceden belirlenen kriterlere uygun biçimde nasıl öğretileceğinin ve değerlendirileceğinin planlandığı çalışmalarda soru sormanın/sorgulamanın öğrencilerin eleştirel düşünme becerilerini geliştirdiğini göstermiştir (King, 1995; Koç, 2007; Helsdingen, van den Bosh, van Gog ve van Merrienboer, 2010; Amanvermez-İncirkuş ve Beyreli, 2020).

Türkçe derslerinde eleştirel düşünme eğitiminin nasıl yapılandırılması gerektiğiyle ilgili olarak sonraki çalışmalarda aynı veya farklı sınıf düzeyinde farklı yayınevlerine ait ders kitaplarında yer alan metni anlama soruları eleştirel düşünme becerilerine göre incelenebilir. Metni anlama soruları dışında Türkçe ders kitaplarında yer alan anlama ve değerlendirmeye yönelik etkinler eleştirel düşünme becerilerine göre incelenebilir. Süreç ve/veya ürün odakll, sınıf düzeyi ve metin türüne özgü strateji yöntem tekniklerin kullanıldığı, aynı sınıf düzeyinde veya farklı sinıf düzeylerinde içerikle bütünleştirilmiş sorular aracıllğıyla Türkçe derslerinde belirlenen kriter/beceri tanımlarına göre öğrencilerin eleştirel düşünme becerilerinde farklılaşma olup olmadığını araştıran karşılaştırmalı deneysel çalışmalar yapılabilir.

Ders kitabı yazarlarının, metinle ilgili soru/etkinlik hazırlarken hem sınıf seviyesini hem de metin türünü göz önünde bulundurarak Türkçe dersleri için belirlenen eleştirel düşünme kriterlerine göre amaca yönelik soru/etkinlik hazırlamalarının Türkçe Öğretim Programlarında öğrenciler için belirtilen 21. yüzyıl hedef kazanımlarını gerçekleştirmek açısından faydalı olacağı söylenebilir. Eleştirel düşünme eğitimi için öğretmenlerin de ders akışını öğrencilerin hazırbulunuşluk seviyelerini göz önünde bulundurarak hazırlamaları; öğretmek istedikleri eleştirel düşünme becerilerini sınıf içi etkinliklerle bütünleştirerek hangi durumlarda nasıl öğreteceklerini planlamaları gerekir.

Adres Address

RumeliDE Dil ve Edebiyat Araşttrmalar Dergisi $\quad$ RumeliDE Journal of Language and Literature Studies Osmanağa Mahallesi, Mürver Çiçeği Sokak, No:14/8 Osmanağa Mahallesi, Mürver Çiçeği Sokak, No:14/8 Kadıköy - İSTANBUL / TÜRKIYE 34714 Kadıköy - ISTANBUL / TURKEY 34714 e-posta: editor@rumelide.com e-mail: editor@rumelide.com, tel: +90 505 7958124, +90 2167730616 phone: +90 505 7958124, +90 2167730616 
Examining text comprehension questions in Turkish textbooks according to critical thinking skills / F. Amanvermez İncirkuş; K. Özçetin (pp. 290-311)

\section{Kaynakça}

Altan, G. (2020). Ortaokul öğrencilerinin eleştirel düşünme becerilerinin bazı demografik özelliklere göre incelenmesi (Yüksek lisans tezi), Eğitim Bilimleri Enstitüsü, Akdeniz Üniversitesi, Antalya.

Amanvermez İncirkuş, F. ve Beyreli, L. (2019). Öyküleyici metinler aracıllğıyla eleştirel düşünme becerilerini değerlendirmeye yönelik bir rubrik. Ana Dili Ĕ̆itimi Dergisi, 7(3), 597-629.

Amanvermez İncirkuş, F. ve Beyreli, L. (2020). Bilişsel Farkındalık Okuma Stratejilerinin Eleştirel Düşünmeye Etkisi: Karma Araştırma Yöntemi. Eğitim ve Bilim, 45(202). doi: 10.15390/EB.2020.7857

Ay, Ş., ve Akgöl, H. (2008). Eleştirel düşünme gücü ile cinsiyet, yaş ve sınıf düzeyi. Kurumsal Eğitimbilim Dergisi, 1(2), s. 65-75.

Browne, M. N. ve Keeley, S. M. (2007). Asking the right questions: A guide to critical thinking (8th Ed). New Jersey: Pearson Prentice Hall.

Büyüköztürk, Ş., Kılıç Çakmak, E., Akgün, Ö. E., Karadeniz, Ş., \& Demirel, F. (2012). Örnekleme yöntemleri. PegemA Yayıncllı, Ankara.

Demir, M. K. (2006). İlköğretim dördüncü ve beşinci sınıf öğrencilerinin sosyal bilgiler derslerinde eleştirel düşünme düzeylerinin çeşitli değişkenler açısından incelenmesi. Gazi Üniversitesi Gazi Ĕ̈itim Fakültesi Dergisi, 26(3), 155-170.

Dickson, S. V., Simmons, D. C. ve Kame'enui, E. J. (1998). Text organization: Research bases. D. C. Simmons ve E. J. Kame'enui (Eds.). What reading research tells us about children with diverse learning needs: Bases and basics içinde (ss. 239-279). Mahwah, NJ: Lawrence Erlbaum Associates.

Diker Coşkun, Y. (2013). Türkçe ders kitaplarının PISA sınavı okuma ölçütleri açısından incelenmesi. Mehmet Akif Ersoy Eğitim Fakültesi Dergisi, 13(26), s. 22-43.

Ennis, R. H. (1993). Critical thinking assesment. Theory Into Practice, 32(3), 179-186.

Ennis, R. ve Millman, J. (2005). Cornell critical thinking test level X. Erişim adresi: https://www.criticalthinking.com/cornell-critical-thinking-test-level-x.html.

Facione, P.A. (2015). Critical thinking: What is and why it counts. 1-30. https://www.insightassessment.com/Resources/Importance-of-Critical-Thinking/CriticalThinking-What-It-Is-and-Why-It-Counts/Critical-Thinking-What-It-Is-and-Why-It-CountsPDF.

Ford-Connors, E. ve Robertson, D. A. (2017). What Do I Say Next? Using the Third Turn to Build Productive Instructional Discussions. Journal of Adolescent \& Adult Literacy, 61(2), 131-139.

Helsdingen, A. S., van den Bosch, K., van Gog, T. ve van Merrienboer, J. J. G. (2010). The effects of critical thinking instruction on training complex decision making. Human Factors, 52(4), 537545 .

King, A. (1995). Designing the instructional process to enhance critical thinking across the curriculum: Inquiring minds really do what to know: Using questioning to teach critical thinking. Teaching of Psychology, 22(1), 13-17.

Koç, C. (2007). Aktif öğrenmenin okuduğunu anlama, eleştirel düşünme ve sinıf içi etkileşim üzerindeki etkileri (Doktora Tezi), Eğitim Bilimleri Enstitüsü, Dokuz Eylül Üniversitesi, İzmir.

Korkmaz, Ö. ve Yeşil, R. (2009). Öğretim kademelerine göre öğrencilerin eleştirel düşünme düzeyleri, Ahi Evran Üniversitesi Eğitim Fakültesi Dergisi, 10(2), 19-28.

Learning Development (2010). Critical thinking. Plymouth University. Erişim adresi: https://www.plymouth.ac.uk/uploads/production/document/path/1/1710/Critical_Thinking.p df.

Lynch, C. L. ve Wolcott, S. K. (2001). Helping your student develop critical thinking skills. Manhattan, Kansas: WolcottLynch Associates, The Idea Center. Erişim adresi:

\begin{tabular}{|c|c|}
\hline & \\
\hline alarn $D$ & d Literatur \\
\hline $\mathrm{Mal}$ & Mahallesi, Mürver Çiçeği Sokak, No:14/8 \\
\hline Kadıköy & STANBUL / TURKEY 34714 \\
\hline $\begin{array}{r}\text { e-posta: edito } \\
\text { tel: }+905057958124,+\end{array}$ & $\begin{array}{l}\text { editor@rumelide.com, } \\
\text { +90 505 7958124, +90 } 216773 \text { o } 616\end{array}$ \\
\hline
\end{tabular}


http://www.ideaedu.org/Portals/o/Uploads/Documents/IDEA\%20Papers/IDEA\%20Papers/I DEA_Paper_37.pdf.

MacKnight, C. B. (2000). Teaching critical thinking through on line discussion. Educause Quarterly, $4,38-41$.

Merriam, S.B. (2018). Nitel araştırma: desen ve uygulama için bir rehber (3. bs.). Çev. Ed. S. Turhan. Ankara: Nobel Akademik.

Miles, M, B. ve Huberman, A. M. (1994). Qualitative data analysis: An expanded sourcebook. (2nd ed). Thousand Oaks, CA: Sage.

Millî Eğitim Bakanlığı (2006). İlköğretim Türkçe dersi $(6,7,8$.) sinıflar öğretim programı. Ankara.

Millî Eğitim Bakanlığı (2013). PISA 2012 ulusal ön raporu. Ankara: Yenilik ve Eğitim Teknolojileri Genel Müdürlüğü.

Millî Eğitim Bakanlığı (2016). PISA 2015 ulusal ön raporu. Ankara: Ölçme, Değerlendirme ve Sınav Hizmetleri Genel Müdürlüğ̈̈. Erișim adresi: http://odsgm.meb.gov.tr/test/analizler/docs/PISA/PISA2015_Ulusal_Rapor.pdf.

Millî Eğitim Bakanlı̆̆ (2019a). Türkçe dersi öğretim programı (İlkokul ve Ortaokul 1, 2, 3, 4, 5, 6, 7 ve 8). Ankara: Milli Eğitim Bakanlığı. Erişim adresi: http://mufredat.meb.gov.tr/ProgramDetay.aspx?PID=332.

Millî Eğitim Bakanlı̆̆ı (2019b). PISA 2018 Türkiye ön raporu. Ankara: Eğitim Analiz ve Değerlendirme Raporları Serisi (No: 10).

Nosich, G. M. (2015). Eleştirel düşünme rehberi (Eleştirel Düşünme ve Disiplinlerarası). (B. Aybek, Çev.), Ankara: Anı.

Özdemir, B. (2011). İlköğretim 1 ? 5. sinıflar Türkçe ders kitaplarında kullanılan okuduğunu anlama sorularını incelenmesi (Yüksek Lisans Tezi). Eğitim bilimleri Enstitüsü, Ankara: Ankara Üniversitesi.

Özdemir, S. M. (2005). Üniversite Öğrencilerinin eleştirel düşünme becerilerinin çeşitli değişkenler açısından değerlendirilmesi. Türk Eğitim Bilimleri Dergisi, 3(3), 297-316.

Özkaya, S. D. (2020). 5, 6, 7 ve 8. sinıf Türkçe ders kitaplarındaki dil bilgisi kazanımlarmın ve sorularım yenilenmiş Bloom Taksonomisine göre değerlendirilmesi (Yüksek Lisans Tezi). Sosyal Bilimler Enstitüsü, Çankırı Karatekin Üniversitesi, Çankırı.

Partnership for 21st Century Skills- A Network of Battelle for Kids (2019). Framework for 21st Century Learning. Erişim adresi: http://static.battelleforkids.org/documents/p21/P21_Framework_Brief.pdf

Patton, M.Q. (2002). Qualitative research and evaluation methods (3. bs.). Thosuand Oaks, CA: Sage.

Paul, R. ve Elder, L. (2006). The miniature guide to critical thinking: Concepts and tools. The Foundation for Critical Thinking. https://www.criticalthinking.org/files/Concepts_Tools.pdf.

Paul, R.W. (2012). Bloom's taxonomy and critical thinking instruction: Recall is not knowledge. J. Willsen ve A. J. A. Binker (Eds.), Critical thinking: What every person needs to survive in a rapid wold. Tomales, CA: Foundation For Critical Thinking. Erişim adresi: http://www.criticalthinking.org/data/pages/26/85578917d13eb2f2bcccd3dao5ao55eb51366eca eo5e8.pdf.

Raphael, T.E. ve Au, K. H. (2005). QAR: Enhancing comprehension and text taking Across grades and content area. The Reading Teacher, 59(3), 206-221.

Ritchhart, R., Church, M. ve Morrison, K. (2011). Making thinking routines visible: How to promote engagement, understanding, and independence for all learners. San Fran- cisco, CA: JosseyBass.

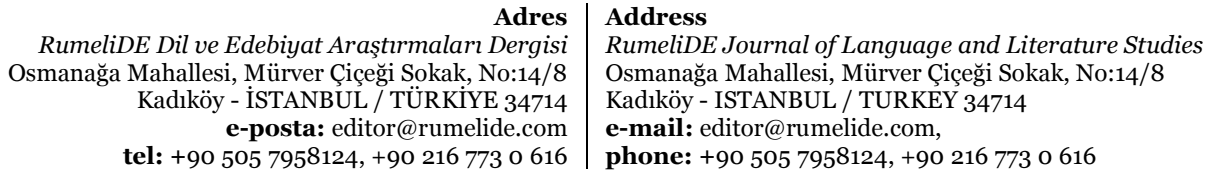

tel: +90 505 7958124, +90 2167730616

phone: +90 5057958124 , +90 216773 o 616 
Examining text comprehension questions in Turkish textbooks according to critical thinking skills / F. Amanvermez İncirkuş; K. Özçetin (pp. 290-311)

Schmit, J. S. (2002). Practicing critical thinking through inquary into literature. J. Holden ve J. S. Schmit (Eds.), Inquiry and the literacy text: Constucting discussions in the English classroom. Classroom practicing in teaching English. 32, Urbana: National Council of Teachers of English.

Şahin, E. (2006). Açık ilköğretim ve ilköğretim Türkçe ders kitaplarındaki soruların OKS Türkçe sorularıyla örtüşme düzeyi (Doktora Tezi). Sosyal Bilimler Enstitüsü, Erzurum: Atatürk Üniversitesi.

Willingham, D. T. (2007). Critical thinking: Why is it so hard to teach. American Educator, 8-19. Erişim adresi: https://www.aft.org/sites/default/files/periodicals/Crit_Thinking.pdf.

Willingham, D. T. (2019). How to teach critical thinking. Education Future Frontiers: Occasionel Paper Series, State of New South Wales (Department of Education). Erişim adresi: http://www.danielwillingham.com/uploads/5/o/o/7/5007325/willingham_2019_nsw_critical _thinking2.pdf.

\section{İncelenen kaynak ders kitapları}

Eselioğlu, H., Set, S. ve Yücel, A. (2019). Ortaokul ve imam hatip ortaokulu Türkçe 8 ders kitabı. Ankara: MEB.

Çapraz Baran, Ş. ve Diren, E. (2019). Ortaokul ve imam hatip ortaokulu Türkçe 5. sinıf ders kitabı. Ankara: Anittepe.

Ceylan, S., Duru, K., Erkek, G. ve Pastutmaz, M. (2019). Ortaokul ve imam hatip ortaokulu Türkçe 6 ders kitabı. Z. Batur ve S. Ceylan (Ed.). Ankara: MEB.

Kır, T., Kırman, E. ve Yağız, S. (2019). Ortaokul ve imam hatip ortaokulu Türkçe 7 ders kitabı. Ankara: MEB.

Ek-1: Türkçe derslerinde eleştirel düşünmeye yönelik beceriler ve soru örnekleri/kökleri

\begin{tabular}{|c|c|c|}
\hline Beceriler & Alt Beceriler & Sorular \\
\hline $\begin{array}{l}\text { Tanımlama: Konuyu } \\
\text { belirleme, tanıtma ve } \\
\text { problemi/konuyu önceki } \\
\text { bilgilerle birlikte ele } \\
\text { alma. }\end{array}$ & $\begin{array}{l}\text { Belirleme } \\
\text { Tarif etme } \\
\text { Sinıflama } \\
\text { Siralama } \\
\text { Seçme } \\
\text { Betimleme }\end{array}$ & $\begin{array}{l}\text { Kim? } \\
\text { Ne? } \\
\text { Nerede? } \\
\text { Nasil? } \\
\text { Ne zaman? } \\
\text {...yl tarif et? }\end{array}$ \\
\hline $\begin{array}{l}\text { Yorumlama: İlkelerin, } \\
\text { olguların neden, niçin ve } \\
\text { nasıl olduğunu } \\
\text { öğrencinin kendi } \\
\text { cümleleriyle açılklaması, } \\
\text { konuya ilişkin örnek } \\
\text { vermesi ve konudan ne } \\
\text { anladığını yorumlaması } \\
\text { beklenir. }\end{array}$ & $\begin{array}{l}\text { Metindeki ilişkileri açıklama } \\
\text { Benzerlik ve farklılıkları } \\
\text { belirleme } \\
\text { Karşılaştırma yapma } \\
\text { Örnek verme } \\
\text { Özetleme } \\
\text { Anlamı açıklama }\end{array}$ & $\begin{array}{l}\text { Bu metnin ana/yardımcı fikrini açıklayınız? } \\
\text { Verilmek istenen mesaj nedir? } \\
\text {... ne anlama gelmektedir? } \\
\text {...yla ne anlatılmak isteniyor? } \\
\text {...ya örnek veriniz? }\end{array}$ \\
\hline
\end{tabular}

\footnotetext{
RumeliDE Dil ve Edebiyat Araşttrmaları Dergisi Osmanağa Mahallesi, Mürver Ciçeği Sokak, No:14/8 Kadıköy - İSTANBUL / TÜRKIYE 34714 e-posta: editor@rumelide.com 


\begin{tabular}{|c|c|c|}
\hline $\begin{array}{l}\text { Analiz: Belli olayların } \\
\text { nedenleri ve sonuçları } \\
\text { arasındaki ilişkiyi } \\
\text { belirleme; genelleme ve } \\
\text { sonuçlara dayanarak } \\
\text { delilleri açı̆ga çıarma, } \\
\text { ayrintıları keşfetme. } \\
\text { (Birden fazla cevabı } \\
\text { vardır ve cevap metinde } \\
\text { yer almaz.) }\end{array}$ & $\begin{array}{l}\text { Parçalara ayırma } \\
\text { Olgular arası ilişkilerin } \\
\text { belirlenmesi } \\
\text { Gerekçelendirme } \\
\text { Farklılığı bulma } \\
\text { Destekleme. }\end{array}$ & $\begin{array}{l}\text { Neden?/Niçin?/Nasıl? } \\
\text {...nın ... üzerindeki etkisini belirtiniz. } \\
\text {......yı nasıl etkiler? } \\
\text {...nın gerekçeleri/sonuçları nelerdir? } \\
\text {...nın sebep-sonuçları nelerdir? } \\
\text {...nın ...ya benzeyen/...nın ...dan farklı olan yanları } \\
\text { nelerdir? } \\
\text {...yla ... arasında nasıl bir ilişki/bağlantı var? } \\
\text {......ya nasıl uyarlanabilir? } \\
\text {... arasındaki zıtlıklar veya karşılaştırmalar } \\
\text { nasıldır? }\end{array}$ \\
\hline $\begin{array}{l}\text { Çıarim: Eldeki } \\
\text { verilerin analizini } \\
\text { yaparak sonuca ulaşma. }\end{array}$ & $\begin{array}{l}\text { Bir sonuca varma, karar verme, } \\
\text { tanımlama, alternatif sunma, } \\
\text { genelleme yapma, planlama, } \\
\text { tahmin etme vb. için } \\
\text { ipuçlarından ve belli } \\
\text { standartlardan yararlanma. }\end{array}$ & $\begin{array}{l}\text {...dan hangi sonucu çıkartıyorsun? } \\
\text {...dan çıkardığın şey nedir? }\end{array}$ \\
\hline $\begin{array}{l}\text { Açıklama: Sonuç } \\
\text { çıarma, sorgulama, } \\
\text { anlamı belirleme, görüş } \\
\text { sunma gibi düşünme } \\
\text { süreçlerini tekrar } \\
\text { anlatabilme. }\end{array}$ & $\begin{array}{l}\text { Sonuçları belirtme } \\
\text { Yapilan şeyleri savunma } \\
\text { Görüşs sunma. }\end{array}$ & $\begin{array}{l}\text { Araştırmanın sonuçları ve belli bulguları nelerdir? } \\
\text { Lütfen bize bu analizi nasıl yürüttüğünüzü } \\
\text { açıklayınız. } \\
\text { Bu çıarıma nasıl ulaştınız? Gerekçelerinizi bize bir } \\
\text { kez daha anlatınız. } \\
\text { Neden böyle düşündünüz? Niçin böyle bir karar } \\
\text { verdiğinizi nasıl açılarsınız? }\end{array}$ \\
\hline $\begin{array}{l}\text { Varsayımda } \\
\text { Bulunma: Tahmin } \\
\text { etme, öngörüde } \\
\text { bulunma, alternatif } \\
\text { sunma. }\end{array}$ & $\begin{array}{l}\text { Tahmin etme } \\
\text { Önerme. }\end{array}$ & $\begin{array}{l}\text {... olursa, ne olur? } \\
\text {... olsaydı, ne farklı olurdu? } \\
\text {... görüşüyle ilgili tahminlere göre neler olacak? } \\
\text {... olsaydı/olmasaydı ne olurdu? }\end{array}$ \\
\hline $\begin{array}{l}\text { Değerlendirme: } \\
\text { Kanıtların, fikirlerin, } \\
\text { varsayımların, } \\
\text { önyargıların, görüşlerin, } \\
\text { bakış açlarının vb.nin } \\
\text { geçerliliğini, etkililiğini, } \\
\text { önemini, avantajlarını, } \\
\text { haklllı̆ını, etkisini, } \\
\text { gerçekliğini } \\
\text { değerlendirme. }\end{array}$ & $\begin{array}{l}\text { Karar verme } \\
\text { Değer biçme } \\
\text { Önemini belirleme, Doğrulama } \\
\text { Katılma/katılmama } \\
\text { Bakış açısı geliştirme }\end{array}$ & $\begin{array}{l}\text {..nın iyi veya kötü olduğunu düşünüyor musun? } \\
\text { Neden? } \\
\text {...nın doğru veya yanlış olduğunu düşünüyor } \\
\text { musun? Neden? } \\
\text {... hakkındaki düşüncelerin neler? } \\
\text {...ya katılldı̆ıı veya katılmadığın yerler neler? } \\
\text {... olsaydı nasıl hissederdin? } \\
\text {...nın lehine ve aleyhine olan şeyler neler? } \\
\text {...yla ilgili probleme/konuya/ /anlaşmazlığa } \\
\text { bulunacak en iyi çözüm nedir? Neden? }\end{array}$ \\
\hline
\end{tabular}

Address

RumeliDE Journal of Language and Literature Studies

Osmanağa Mahallesi, Mürver Çiçeği Sokak, No:14/8

Kadıköy - ISTANBUL / TURKEY 34714

e-mail: editor@rumelide.com,

phone: +90 505 7958124, +90 2167730616 